\title{
Performance evaluation and parameters sensitivity of a distributed hydrological model for a semi-arid catchment in India
}

\author{
V D Loliyana and P L PATEL* \\ Department of Civil Engineering, SVNIT Surat, Surat 395 007, India. \\ *Corresponding author. e-mail: premlalpatel1966@gmail.com
}

MS received 26 September 2017; revised 24 January 2018; accepted 12 February 2018; published online 26 October 2018

In present study, a distributed physics based hydrological model, MIKE SHE coupled with MIKE 11 , is calibrated using multi-objective approach, i.e., minimization of error in prediction of stream flows and groundwater levels, using the data of eight years from 1991 to 1998 of Yerli sub-catchment $\left(\right.$ area $\left.=15,881 \mathrm{~km}^{2}\right)$ of upper Tapi basin in India. The sensitivity analyses of thirteen model parameters related with overland flow, unsaturated and saturated zones have been undertaken while simulating the runoff volume, peak runoff at catchment outlet and groundwater levels within the catchment with wide variations $( \pm 50 \%)$ in the model parameters. The calibrated model has also been validated for prediction of stream flow and groundwater levels within the Yerli sub-catchment for period 1999-2004. The simulated results revealed that calibrated model is able to simulate hydrographs satisfactorily for Yerli sub-catchment $(\mathrm{NSE}=0.65-0.89, r=0.80-0.95)$ at daily and monthly time scales. The ground water levels are predicted reasonably satisfactorily for the plain area (RMSE $=0.50-6.50 \mathrm{~m})$ in the study area. The results of total water balance indicated that about $78 \%$ of water is lost from the system through evapotranspiration, out of which about $3.5 \%$ is contributed from the groundwater zone.

Keywords. Distributed approach; hydrological modelling; calibration; sensitivity analysis; Yerli catchment.

\section{Introduction}

The depleting water resources under changing climatic conditions and increasing population across the globe is a major challenge for meeting the demands of domestic, agricultural and industrial sectors. Prediction of water availability in spatial and temporal scales is primarily required for planning rain water harvesting and conservation measures, particularly in arid and semi-arid catchments. The mesoscale physics based distributed hydrologic models are useful in better understanding of detailed hydrological water balance of larger catchments, and taking decisions in their management practices. Many mesoscale lumped (HEC-HMS, IHACRES, MIKE 11 NAM, XAJ), semi-distributed (DPHM-RS, HBV, SWAT) as well as distributed hydrological models (TOPMODEL, VIC, MIKE SHE) have been developed in recent decades to simulate hydrological processes at catchment scales. The distributed hydrological models are favourable over lumped conceptual models as former provide a comprehensive approach in characterizing spatial variability of the basin in terms of topography, land use/cover, soil types and runoff at finer scales. 
Refsgaard (1997) emphasised the need of physics based distributed model over lumped conceptual model, in prediction of groundwater levels, stream flows at internal sites, and possibility of assessing the impact of future land use and climate changes within the catchment. Madsen (2003) formulated consistent framework of MIKE SHE for making its application on Danish Karup catchment $\left(440 \mathrm{~km}^{2}\right)$ and indicated that multi objectives auto-calibration approach gives better results vis-à-vis single objective approach being used in previous investigations. El-Nasr et al. (2005) compared the better performance of MIKE SHE over SWAT (semi-distributed) model while applying the same in Jeker river basin (area of $465 \mathrm{~km}^{2}$ ), Belgium in prediction of river discharge, accumulated volume of runoff under extreme flow conditions in the basin. Sahoo et al. (2006) applied MIKE SHE model in a flashy mountains Manoa-Palola stream system on the Island of Oahu, Hawaii, USA. The sensitivity analysis of the model parameters indicated that Manning's roughness coefficient of the watershed and hydraulic conductivities of the saturated zone were the most sensitive parameters in determining the shape of the flood peaks. Also, 'drainage time constant' was found to be more sensitive vis-à-vis 'drainage depth' in simulation of base flow. Zhang et al. (2008) demonstrated that MIKE SHE model is able to satisfactorily simulate the continuous daily stream flows vis-àvis specific storm events. The saturated hydraulic conductivity of unsaturated porous media and Manning's roughness coefficient of overland flow were found to be prominent calibration parameters in simulation of stream flows. Vázquez et al. (2009) applied generalised likelihood uncertainty estimation (GLUE) method for assessing the performance of distributed hydrological MIKE SHE model of Gete catchment (area of $586 \mathrm{~km}^{2}$ ), Germany. The study estimated prediction accuracy of multi-variables, i.e., daily stream flow, groundwater levels and extreme events in relatively flat catchment. The study further pointed out that auto-calibration technique developed for MIKE SHE by Madsen (2003) seems to be better than Monte Carlo based GLUE approach as latter requires excessive computational effort in searching the parameter in sample space. Im et al. (2009) manually calibrated MIKE SHE model for Gyeongancheon watershed $\left(257.90 \mathrm{~km}^{2}\right)$ in the Korea and validated the same using 'split sampling' procedure. The calibrated model parameters were, subsequently, used to investigate the impact of land use changes on watershed hydrology for period 1980-2000. Dai et al. (2010) evaluated the performance of MIKE SHE model using Bi-criterion analysis, used for construction of uncertainty bounds of model parameters to simulate the hydrological processes, i.e., stream flows and groundwater levels. The sensitivity analysis of hydrological parameters indicated that Manning's roughness coefficient for overland flow, horizontal hydraulic conductivity and drainage depth play significant roles in generating runoff at the catchment outlet. The study concluded that multi criteria calibration could reduce the modelling bias uncertainty, and able to reveal the equifinality at a certain level in distributed hydrological models. Rahim et al. (2012) manually calibrated MIKE SHE distributed model with observed stream flow data within the catchment, and simulated satisfactorily the water balance of Paya Indah wetland $\left(242.21 \mathrm{~km}^{2}\right)$, Malaysia using MIKE SHE distributed model while coupling three phases of hydrological cycle, viz., overland flow, unsaturated flow and ground water flow. Wang et al. (2012) assessed the sensitivity of MIKE SHE model parameters while applying the same on Chahoe catchment in China, and it was revealed that Manning's roughness coefficient, saturated hydraulic conductivity and specific yield, are the significant parameters in simulating the stream flows. The study further suggested that model behaviour can further be improved while applying multi objectives calibration protocol in MIKE SHE model. Qin et al. (2013) used the auto-calibration tool in MIKE SHE for optimizing groundwater level predictions in large North China plain (area of 140,000 $\mathrm{km}^{2}$ and grid size of $2 \times 2 \mathrm{~km}$ ). The simulated groundwater levels in the wells compared satisfactorily with observed water levels in the wells in the region. The water balance of the complete study region was estimated, and the actual evapotranspiration were simulated with observed evapotranspiration from remotely sensed data of the study area.

The Yerli sub-catchment, part of Purna river catchment in India having mountainous to plain topography, is characterised with high evapotranspiration and vast agriculture land. The subcatchment is classified under semi-arid category as its mean aridity index (ratio of rainfall to PET) is around 0.46 . The prediction of ground water levels and stream flows are essentially needed for meeting irrigation, domestic and industrial requirements in the sub-catchment. The study reported 
in the preceding paragraphs clearly indicated that Manning roughness coefficient is one of the significant parameters affecting the stream flows, and multi-objective approach could simulate stream flows and groundwater levels significantly better than single objective approach. None of existing hydrological models, based on multi-objective approach with distributed Manning's roughness parameter, are able to simulate stream flows, groundwater levels and water balance simultaneously within a catchment. Keeping in view the societal requirements for prediction of water availability in the Yerli sub-catchment and research needs, objectives of the present investigation were formulated to (a) assess the predictive capacity of MIKE SHE while considering distributed values of Manning's roughness coefficient, $M$ over the catchment, (b) derive the optimal calibration parameters using multi-objectives optimization approach and auto-calibration tool in MIKE SHE, (c) analyse the sensitivity of MIKE SHE/MIKE 11 coupled model parameters in producing outputs in terms of runoff volume, peak runoff and groundwater levels, and (d) evaluate the performance of calibrated
MIKE SHE model using split sampling procedure for stream flow, groundwater levels and total water balance of selected catchment. The investigation, reported in present study, would be useful in key applications of integrated physics based distributed model MIKE SHE/MIKE 11 for larger catchments, i.e., $>5000 \mathrm{~km}^{2}$, with their varying topographical, hydro-meteorological and hydro-geological conditions.

\section{Study area and data source}

The Yerli sub-catchment drains into the Purna river, which is one of the major tributaries of Tapi river in India (figure 1). The Yerli subcatchment consisting of peripheral basaltic region and central alluvial part, lies between latitudes $20^{\circ} 08^{\prime} 31^{\prime \prime}-21^{\circ} 40^{\prime} 30^{\prime \prime} \mathrm{N}$, and longitudes $75^{\circ} 56^{\prime} 25^{\prime \prime}-$ $77^{\circ} 56^{\prime} 46^{\prime \prime} \mathrm{E}$. The major catchment area is covered in Maharashtra state (95\%), while a smaller part (5\%) in Madhya Pradesh. The Yerli stream gauging site is located on the Purna river (length $\approx 300 \mathrm{~km}$ ), which has its confluence just upstream

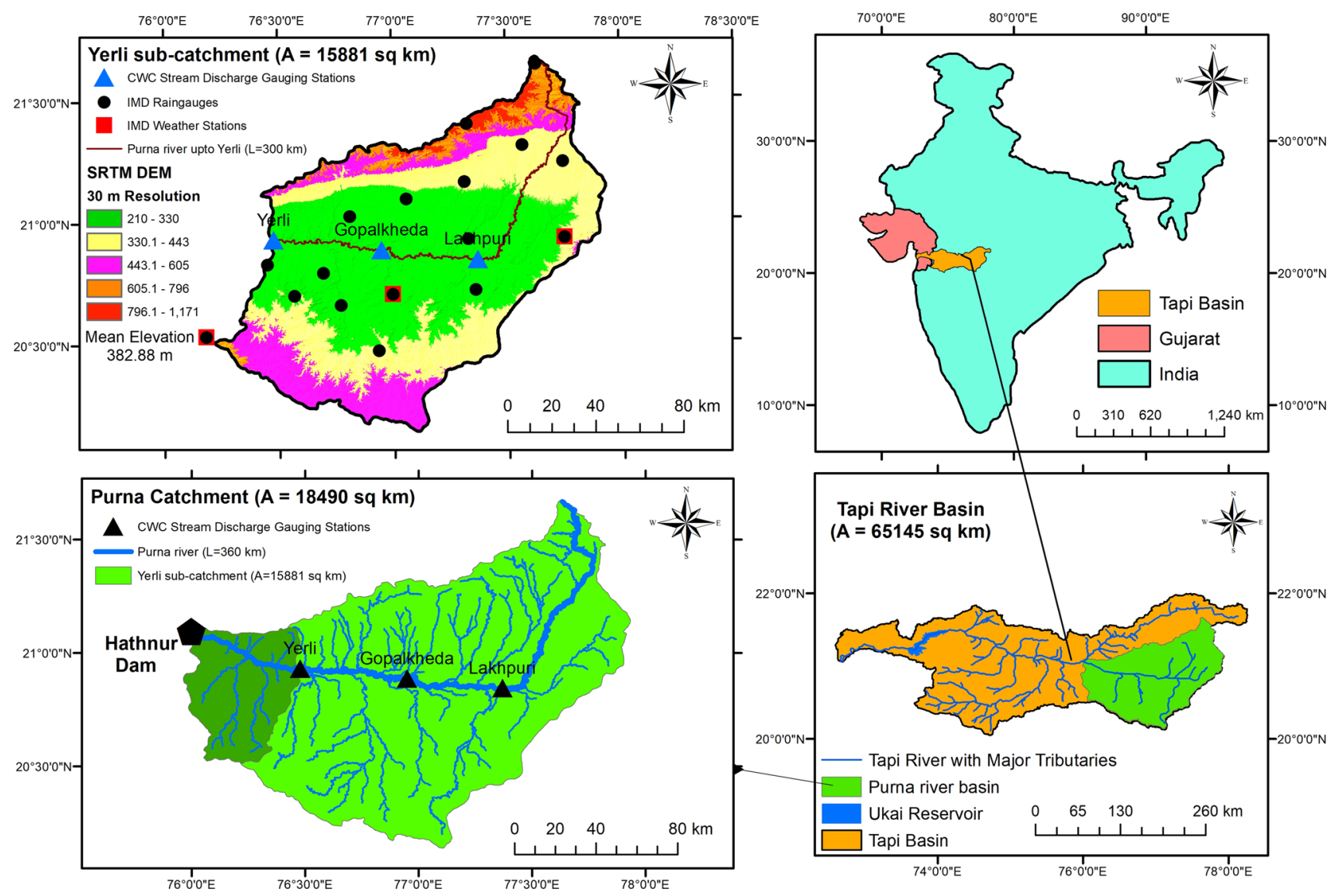

Figure 1. Index map showing geographical location of study area; raingauge and stream gauging sites; and DEM of study area. 
of Hathnur reservoir, and originates from Gawilgarh, steep mountains of eastern Satpura range (Betul district of Madhya Pradesh) (figure 1). The elevation of the catchment ranges from 213 to $1171 \mathrm{~m}$ above the mean sea level (msl). The southwest monsoon sets in by the middle of June, and withdraws by mid-October in the catchment, having an average rainfall (1991-2004) of $785 \mathrm{~mm}$ with significant variations in space and time. The study area experiences very hot summers and moderately cold winters. The summer period normally starts from mid-March and continues up to mid-June. The minimum and maximum temperature ranges from $10-15$ to $38-48^{\circ} \mathrm{C}$, respectively in the catchment (Loliyana and Patel 2015). Average annual (1991-2004) potential evapotranspiration (PET) in the catchment is $1715 \mathrm{~mm}$, and its aridity index (i.e., ratio of rainfall to PET) is 0.46 . The climate in the study area is, thus, classified as semi-arid, as the potential evapotranspiration is 1.6 to 3.17 times of annual rainfall (UNEP 1992; Jain et al. 2007; Spinoni et al. 2015). The agricultural crop is the dominant land use pattern in the catchment, and forms around $65 \%$ of total catchment area. The Cotton, Sorghum, Green Gram, Black Gram, Pigeon Pea are major crops cultivated during Kharif season while Horse Gram, Safflower and Wheat are cultivated during the Rabi season in the study area (Jain and Tambe 2012). The characteristics of dark brown clay soil are fine textured, and sticky in nature. The soils have good water receptivity of around $36.3-45 \%$ in surface layers, and have water holding capacity of around 12.21\% (Jain and Tambe 2012). Geologically, the Yerli sub-catchment consists of upper Gondwanas, Deccan basalt and Quaternary sediments (alluvial deposits) (figure 5a). The Purna alluvial valley (part of Yerli catchment) mainly consists of Quaternary sediments, and its periphery is dominated by the Deccan basalt. The alluvial deposits of Purna catchment ranges from the ages of lower Pleistocene to recent age. The alluvial sedimentary deposits in the valley occur as dissected alluvial cover, alluvial fans, piedmont zone, and older flood plains. Thus, main water bearing formation in the area is alluvium and basaltic lava flows. The alluvium, which covers $7800 \mathrm{~km}^{2}$ area of the Purna river catchment, forms the principal water bearing formation where granular zones are encountered at various depths. The Purna alluvium can be divided into two hydrogeological layers, i.e., younger alluvium extending down to around $80 \mathrm{~m}$ depth below ground level forming potential aquifer (comprising alternate beds of clay and sand) and older alluvium attaining a maximum of $450 \mathrm{~m}$ depth below the ground level (CGWB 2013).

The shuttle radar topography mission (SRTM) digital elevation model (DEM) with 1 arc second $(\sim 30 \mathrm{~m})$ horizontal resolution has been used to represent the land surface elevation of the Yerli catchment (figure 1). The SRTM DEM was downloaded from web portal (http://earthexplorer.usgs. gov/). The toposheets $(1: 50,000)$ were collected from Survey of India, regional offices at Pune and Jabalpur, India for digitizing the river network and catchment delineation. The IRS P6 LISS III satellite imagery of year 2000 (3 scenes, $24 \mathrm{~m}$ horizontal resolution) are obtained from National Remote Sensing Centre, Hyderabad for land use/cover classification. The soil maps (1:250,000 scale) and associated characteristics were obtained from National Bureau of Soil Survey and Land Use Planning (NBSS \& LUP), Nagpur. The spatial extent of geology maps of the Amravati, Akola, Buldana, Washim districts of Maharashtra and Betul district of Madhya Pradesh were collected in hard copy format from the Geological Survey of India (GSI), Nagpur. Meteorological variables, such as daily rainfall, and potential evapotranspiration, were used as input to the hydrological model. The point rainfall data of seventeen rain gauge stations on daily time scale were collected from India Meteorological Department (IMD). The weather data, i.e., minimum and maximum temperature, wind speed, relative humidity, sun-shine hours, vapour pressure at Amravati, Akola, Buldana stations (figure 1), were collected from IMD and used for estimating potential evapotranspiration as input into the model. The potential evapotranspiration from available weather data were estimated using Penman's method (Penman 1948). The additional information on hydrogeology, i.e., exploratory wells (165 nos.) and observation wells (49 nos.) of the catchment were collected from Central Ground Water Board (CGWB), Nagpur, in the form of reports published on Purna alluvial catchment (Jain and Tambe 2012) and, district profile reports of Amravati, Akola, Buldana, Washim, and Betul districts. The irrigation data were taken from the report published by Groundwater Survey Development Authority (GSDA)-CGWB organisation (GSDA 2004), provides a summary of tehsil wise (31 tehsils in Yerli catchment) estimated water withdrawals of irrigation and domestic/industrial drafts as total groundwater draft. The river crosssections, observed daily stream flows and water 
Table 1. Nature of input data and their sources.

\begin{tabular}{|c|c|c|}
\hline Input data & Data type & Data source \\
\hline Topography & Distributed map & $\begin{array}{l}\text { Shuttle Radar Topographic Mission } \\
\text { (SRTM) Digital Elevation Model } \\
\text { (DEM) } 30 \mathrm{~m} \text { data }\end{array}$ \\
\hline River network & Digitized GIS shape files & Survey of India (SoI) toposheets \\
\hline Precipitation & Semi-distributed map (station based) & $\begin{array}{l}\text { India Meteorological Department } \\
(\text { IMD) station data }\end{array}$ \\
\hline Weather data for PET computation & Time series & IMD station data \\
\hline Vegetation & Distributed map & Derived from land use classification \\
\hline Leaf Area Index (LAI) & Constant & From literature \\
\hline Root Depth (RD) & Constant & From literature \\
\hline Soil type & Distributed map & $\begin{array}{l}\text { National Bureau of Soil Survey \& } \\
\text { Land Use Planning (NBSS \& LUP), } \\
\text { Nagpur }\end{array}$ \\
\hline Geology map & Distributed map & $\begin{array}{l}\text { Geological Survey of India (GSI), } \\
\text { Nagpur }\end{array}$ \\
\hline $\begin{array}{l}\text { River cross section, discharge and } \\
\text { water level }\end{array}$ & Time series & $\begin{array}{l}\text { Central Water Commission (CWC) } \\
\text { gauging stations }\end{array}$ \\
\hline
\end{tabular}

levels at Yerli stream gauging station were collected from Central Water Commission (CWC), Government of India. Table 1 summarises brief description of required input data, data type and their respective sources.

\section{Process description and methodology}

\subsection{Brief description of hydrological model}

MIKE SHE (Système Hydrologique Europeén) is a fully distributed, physically based, deterministic macro-scale hydrological model, operates at grid cell level, and capable of both continuous and event based analyses (DHI 2017). In integrated MIKE SHE/MIKE 11 coupled model, a finite difference approach is used to solve the partial differential equations describing the processes of overland (2D Saint Venant equations as diffusive wave approximation), channel flows (1D kinematic wave routing of Saint Venant's equations), unsaturated (2-layer water balance method) and saturated (3D Darcy's equation) flows. The analytical solutions are used for describing the hydrological processes like interception and evapotranspiration (DHI 2017). In MIKE 11, river discharge and stage levels are calculated at ' $Q$ ' and ' $h$ ' points, respectively. The coupling of MIKE SHE and MIKE 11 is established at each h-points. The flow exchange between the surface water and groundwater is estimated as the difference in water table level in the adjacent grid cell and the river cell, multiplied by the conductance value between the two cells. The snowmelt component has been ignored in present study as the study region is free from snowfall region. The model structure adopted in present study using MIKE SHE/MIKE 11 coupled model is illustrated in figure 2 .

\subsection{Description of physical processes}

The MIKE SHE/MIKE 11 coupled hydrological model has been used to simulate the hydrological processes, evapotranspiration, overland flow, stream flow, unsaturated and saturated flows, within the Yerli sub-catchment. Brief description of each hydrological processes are summarised in following paragraphs.

\subsubsection{Evapotranspiration (ET)}

The actual evapotranspiration (AET), includes the evaporation from interception, ponding and evapotranspiration (ET) from the root zone of unsaturated and saturated soil. The AET has been simulated using 2-layer water balance method formulated by Yan and Smith (1994). The unsaturated zone (UZ) is split into parts, viz., root zone from where ET occurs and below root zone where ET does not occur. The soil properties included in 2-layer UZ module are infiltration capacity, and soil moisture constants at saturation, field capacity and wilting point. The AET is estimated using 


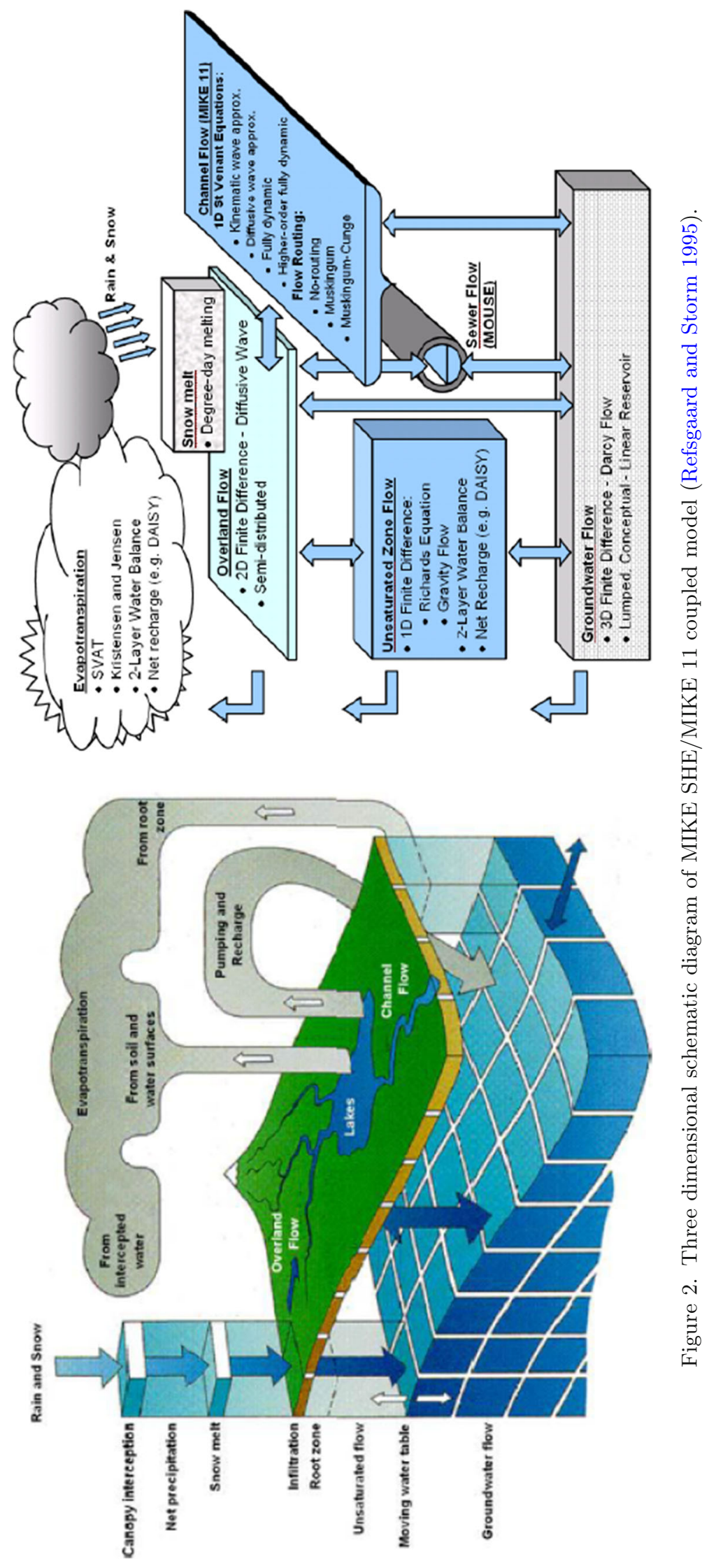


equation (1)

$$
\mathrm{AET}=E_{c}+E_{p}+E_{u}+E_{s} .
$$

Here, $E_{c}$ is daily evaporation from canopy storage, $E_{p}$ is the daily evaporation from soil or ponded water, $E_{u}$ is the daily ET values from unsaturated zone extracted by the plants, and $E_{s}$ is the daily ET from saturated zone extracted by the plants (Wang et al. 2012).

\subsubsection{Overland flow and stream flow}

The overland flow is simulated using 2D diffusive wave approximation of Saint Venant's equation. The input parameters consist of Manning's number $(M)$, and surface detention storage $(\mathrm{mm})$. The Manning's $M(M=1 / n$, where $n$ is Manning's roughness coefficient) has considerable impacts on overland flow to the streams, and stream flows at the outlet of the stream, with higher values leading to quicker water movement. On the other hand, detention storage largely affects routing of water into the stream and water table dynamics. Higher values of detention storage, reduces the overland flow reaching to the stream and increases the ponding water which may lead to rise in the water table level. In present study, kinematic wave approximation has been used for simulation of stream flows in main channel using MIKE 11. In present study, detention storage has been taken as the calibration parameter of hydrological model, and distributed Manning's $M$ for surface roughness, were given as input to model based on land use/land cover in the catchment.

\subsubsection{Unsaturated flow}

The unsaturated flow process is treated as one-D vertical motion as the gravity plays major role during infiltration. In MIKE SHE, coupling of flows saturated and unsaturated is undertaken to capture correct soil moisture in unsaturated porous media and water table dynamics in saturated zone. The MIKE SHE uses three options for calculation of unsaturated flows, viz., full Richard's equation, simplified gravity flow, and 2layer water balance method formulated by Yan and Smith (1994). Keeping in view the larger extent of study region being simulated, and extensive computational efforts needed in implementation of full Richard's equation, a relatively simplified 2layer water balance approach has been used in simulation of flow in unsaturated zone. The soil parameters in UZ include saturated hydraulic conductivity $\left(K_{s}\right)$, soil moisture content at saturation $\left(\theta_{s}\right)$, field capacity $\left(\theta_{f c}\right)$ and wilting point $\left(\theta_{w p}\right)$.

\subsubsection{Saturated flow}

In MIKE SHE, the saturated flow is simulated using finite difference solutions of 3D Darcy's equations. The hydraulic properties of soil, i.e., horizontal and vertical hydraulic conductivity, specific yield and storage coefficient, are major inputs for simulation of saturated flow in the porous media. Horizontal hydraulic conductivity $\left(K_{x x}\right)$ considerably affects base and peak flows, while overland flow, lateral flow, and ground water table are significantly influenced by the vertical hydraulic conductivity $\left(K_{y y}\right)$ of the soil. The drainage depth, a depth from the phreatic surface to the level at which drainage occurs, and the drainage time constant $\left(D_{T}\right)$, are important parameters for simulation of the subsurface flow. The drainage time constant influences the streamflow, and its lower values delay the subsurface flow reaching into the stream. The drainage depth $\left(D_{D}\right)$ considerably affects both the ground water table depth as well as stream flow. As soon as the water table rises above the drainage depth, drainage starts and varies linearly with changes in elevation between drainage depth and water table in the adjoining catchment (Wang et al. 2012; DHI 2017).

\subsection{Methodology}

The brief description of adopted methodology (figure 3) including preparation of input data, initial and boundary conditions, time steps for simulation, model calibration and performance evaluation criteria, are described in following paragraphs:

\subsubsection{Preparation of input data}

The MIKE SHE model formulation works on grid to grid basis. Accordingly, square grids of size $250 \times 250 \mathrm{~m}$ (total of 254,096 finite difference cells) were generated over the study region of Yerli sub-catchment. The SRTM DEM data, at $30 \mathrm{~m}$ resolution, were aggregated to the model grid specification and used as the surface elevation in MIKE SHE model (figure 1). The rainfall data of seventeen rain gauge stations were taken as representative rainfall of the areas which were closer to them, and such areal distribution were obtained using Thiessen polygon network 


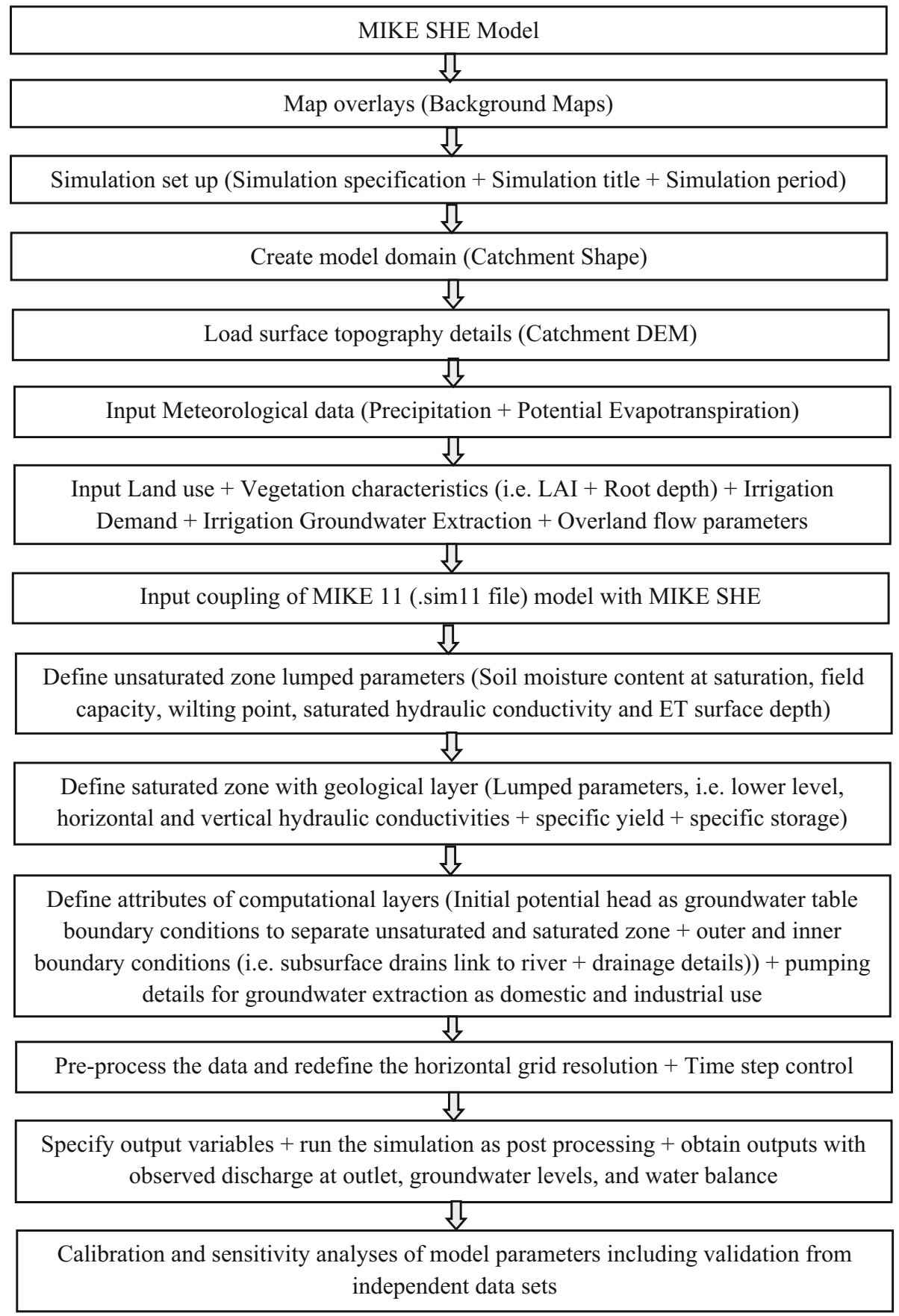

Figure 3. Methodology for development of distributed physics based hydrological model in MIKE SHE.

approach (figure 4a). The estimated potential evapotranspiration (PET) for Amravati, Akola and Buldana stations were taken as input into MIKE SHE model for computation of AET. The time series of PET of each station was distributed based on district area wise in the catchment (figure $4 \mathrm{~b}$ ). The land use/cover analysis was carried out using supervised classification of IRS P6 LISS III satellite imagery of year 2000 in ERDAS Imagine 10.0 for the Yerli sub-catchment. The classified land use pattern for the study area is depicted in figure 4(c). Nine types of land usage, corresponding percentage areas and their respective Manning's $M$ values for overland flow computation are included in table 2. Here, Manning's $M$ (inverse of Manning's roughness coefficient, $n$ ) values were selected from available information in literature for different spatial land use patterns in the sub-catchment (Engman 1986; Chow et al. 1988; Vieux 2001; Kothyari et al. 2010).

Further, the leaf area index (LAI) and root zone depths $(\mathrm{RD})$ are the prime parameters of 


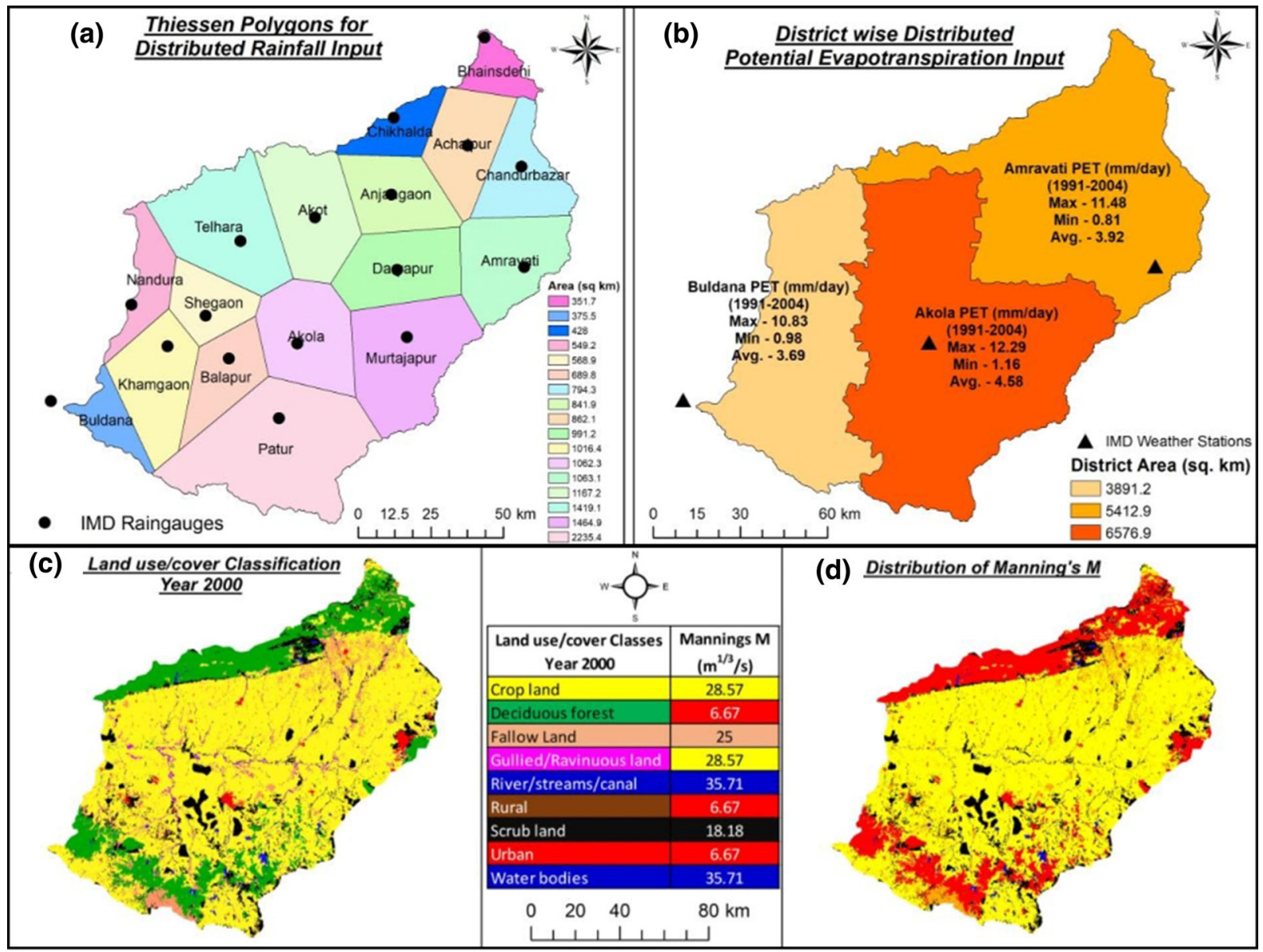

Figure 4. Model inputs (a) distributed rainfall, (b) distributed PET, (c) land use classification, and (d) distributed Manning's $M$ in MIKE SHE model.

Table 2. LAI, RD and Manning's M values for land use pattern of Yerli sub-catchment.

\begin{tabular}{|c|c|c|c|c|c|c|c|}
\hline Land use classes & $\begin{array}{l}\text { Area } \\
\left(\mathrm{km}^{2}\right)\end{array}$ & $\begin{array}{l}\text { Area } \\
(\%)\end{array}$ & LAI & $\begin{array}{l}\text { Wt. avg. } \\
\text { of LAI }\end{array}$ & $\begin{array}{c}\mathrm{RD} \\
(\mathrm{mm})\end{array}$ & $\begin{array}{c}\text { Wt. avg. } \\
\text { of RD (mm) }\end{array}$ & $\begin{array}{c}\text { Manning's } \\
M\end{array}$ \\
\hline Deciduous forest & 2697.09 & 16.98 & 6 & 1.0 & 800 & 135.9 & 6.67 \\
\hline River/streams/canal & 149.38 & 0.94 & 0 & 0.0 & 0 & 0.0 & 35.71 \\
\hline Fallow land & 1030.36 & 6.49 & 4 & 0.3 & 1200 & 77.9 & 25.00 \\
\hline Scrub land & 1153.99 & 7.27 & 6 & 0.4 & 800 & 58.1 & 18.18 \\
\hline Crop land & 10366.00 & 65.27 & 5 & 3.3 & 1083 & 706.9 & 28.57 \\
\hline Urban area & 98.27 & 0.62 & 0 & 0.0 & 0 & 0.0 & 6.67 \\
\hline Rural area & 145.13 & 0.91 & 0.5 & 0.005 & 100 & 0.91 & 6.67 \\
\hline Water bodies & 91.33 & 0.58 & 0 & 0.0 & 0 & 0.0 & 35.71 \\
\hline Gullied/Ravenous land & 149.38 & 0.94 & 6 & 0.1 & 700 & 6.6 & 28.57 \\
\hline Total & 15881.00 & 100 & - & 5 & - & 986 & - \\
\hline
\end{tabular}

vegetation, used for estimation of actual evapotranspiration in MIKE SHE. The weighted average values of LAI and RD were chosen based on literature (Allen et al. 1998; Wijesekara et al. 2014; Foster and Allen 2015), and available cropping pattern (Jain and Tambe 2012) in the study area. The estimated areal average values of LAI and RD are included in table 2. The available soil data were digitized into vector format in ArcGIS 10.4. The soil data were available in 37 soil classes depending upon local variances such as geology and topography of sub-catchment. The soil depths vary between 10 and $150 \mathrm{~cm}$ in the catchment.

The bed rock surface is, invariably, the lower boundary of the saturated zone module within the catchment. The data of exploratory wells (165 nos.) 

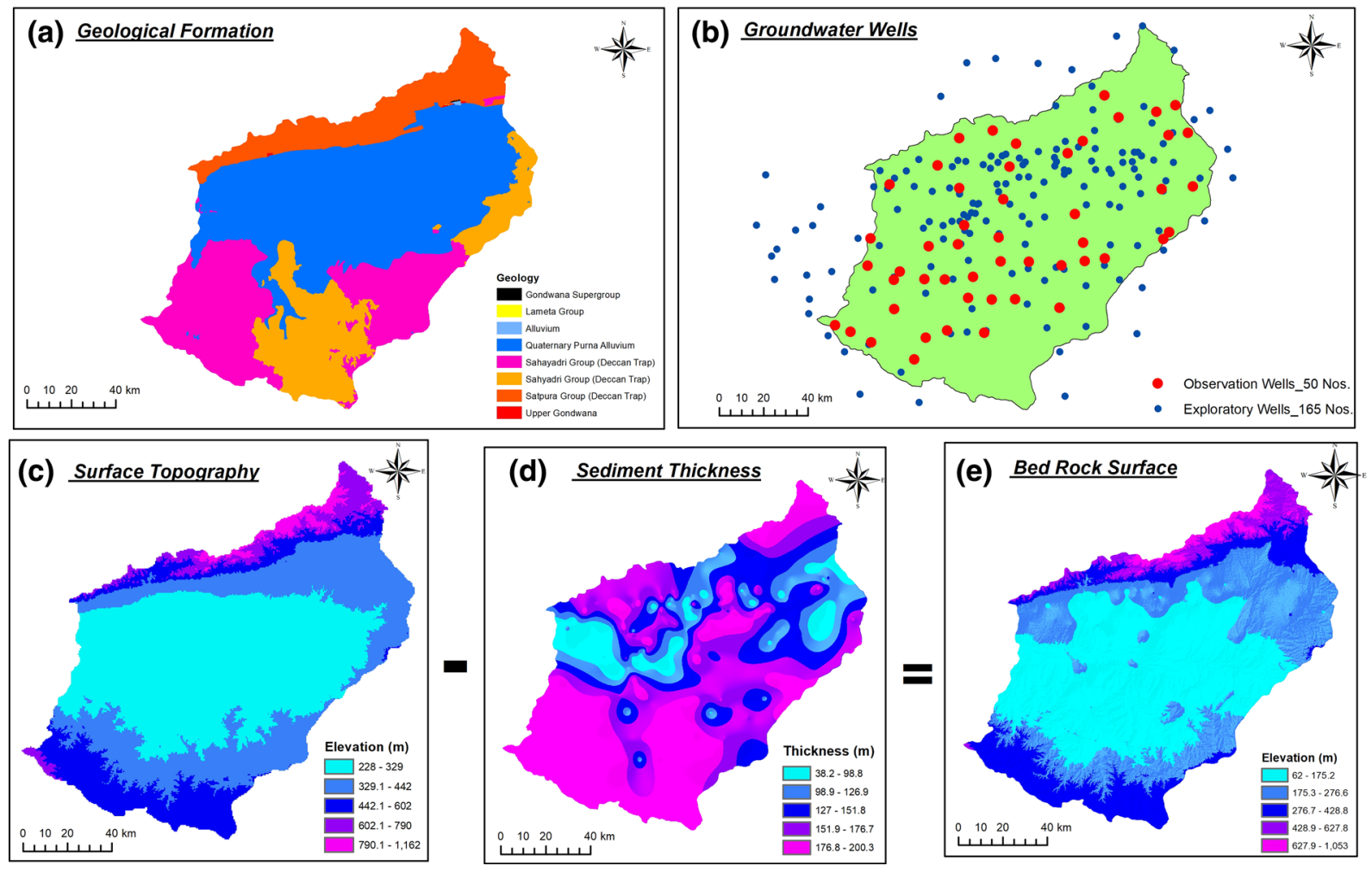

Figure 5. Geology, location of wells, and bed rock surface for development of model.

(figure 5b) were used for creating bathymetry of saturated zone up to $200 \mathrm{~m}$. The geological thickness of the soil/rock formation below the ground level up to basalt rock surface (varies from 38.2 to $200.3 \mathrm{~m}$ ) was obtained using well lithology, and converting the same into the raster of sediment thickness raster (figure 5d) using topo to raster interpolation tool of ArcGIS 10.4. The raster of lower boundary of saturated zone, i.e., bed rock surface (figure 5e), was obtained by subtracting the raster of sediment thickness from the surface DEM (figure 5c). The groundwater level data of observation wells were used for assessing the performance of simulated groundwater levels within the catchment.

There are total 31 tehsils (Talukas) in the study area (figure 6a). Tehsil wise groundwater drafts for irrigation and domestic/industrial demands were estimated from available data for year 2004 of the study area (figure $6 \mathrm{~b}$ and c). It is estimated that out of total groundwater draft of $1590 \mathrm{Mm}^{3}$, irrigation and domestic/industrial drafts are 837 and $53 \mathrm{Mm}^{3}$, respectively, in Yerli sub-catchment. The tehsil-wise groundwater irrigation drafts were applied by locating one irrigation groundwater well in each tehsil (figure 6b). Likewise, domestic/industrial groundwater drafts were applied by defining one groundwater well for each tehsil at prominent urban/village centres. In all, 29 domestic/industrial extraction wells were defined in the study domain (figure 6c). Figure 6(d) depicts maximum groundwater extraction discharge rate of each tehsil based on irrigation supply during year 2004 in the study region.

\subsubsection{Initial and boundary conditions}

Initially, the model was run as hot start run for period $01-01-1986$ to $31-12-1990$, for setting the initial conditions of model calibration. The hot start run was required for stabilizing the dynamics of ground water level conditions in the model. The potential heads for geological layer, derived from 'hot start' run, was used as the initial conditions in the model for simulation of unsaturated and saturated water movements. The zero-flux boundary conditions were assigned to three sides of Yerli subcatchment, as it is bounded by the watershed lines of Upper Tapi river in northern part, and Godavari river watershed lines at eastern and southern sides. The fixed head boundary condition was used at western boundary, representing the outlet of Purna river at Yerli stream gauging station. For simulation of river flow using MIKE 11, a constant 

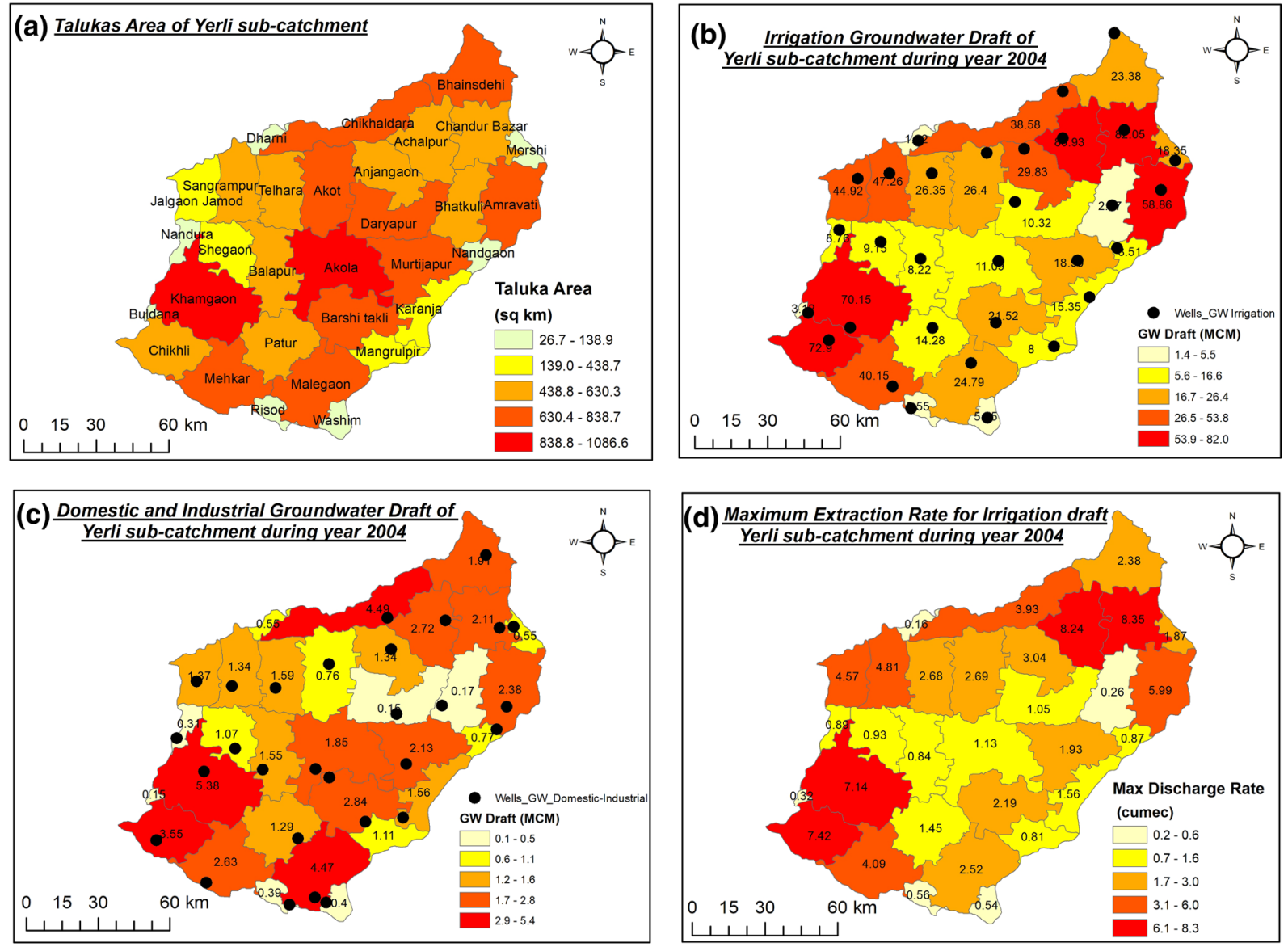

Figure 6. Tehsil-wise irrigation, groundwater drafts and maximum extraction rates for irrigation draft (based on year 2004).

discharge of $0.1 \mathrm{~m}^{3} / \mathrm{s}$ at origin of the river and time series of water levels at Yerli stream gauging station, were taken as upstream and downstream boundary conditions, respectively.

\subsubsection{Time steps for simulation}

Variable time steps have been used for simulation of different flow characteristics and hydrological modelling components in MIKE SHE. In present study, maximum allowable time steps for channel flow; overland flow, ET and unsaturated flow; and saturated flow were set as 6, 12 and $24 \mathrm{hr}$, respectively. The output for stream flow were generated at interval of $24 \mathrm{hr}$.

\subsubsection{Performance evaluation criteria}

The performance of the MIKE SHE model under calibration/validation stages were evaluated at Yerli stream gauging station using statistical performance indices, like, mean absolute error (MAE), correlation coefficient $(r)$, Nash-Sutcliffe efficiency (NSE), root mean squared error (RMSE) and efficiency index (EI) (Appendix).

\subsubsection{Model calibration}

The parameters of MIKE SHE model, for simulating stream flows at Yerli stream gauging station, have been calibrated and validated for periods, 1991-1998 and 1999-2004, respectively. The periods of calibration and validation processes were chosen such that wet $(1994,1998,1999,2002)$, average $(1992,1993,1996,1997,2001)$ and dry (1991, 1995, 2000, 2003, 2004) years are included in calibration and validation of the hydrological model (figure 7).

Initial values of the model parameters were chosen based on existing conditions in the catchment, available information in literature and modelling perception. The model calibration has been carried out using auto-calibration technique, i.e., AUTOCAL tool of DHI package (Madsen 2003). It is a population evolution based algorithm, i.e., shuffle complex evolution algorithm, in which probabilistic Latin hypercube sampling technique is used for calibration of optimal parameters. The auto-calibration procedure, in present study, has been adopted for optimizing two objective 




Figure 7. Rainfall, PET and observed runoff for Yerli sub-catchment during 1991-2004.

functions, i.e., (i) overall agreement of the shape of the hydrograph (minimizing the overall root mean square, RMSE of daily discharge) and (ii) overall agreement of the groundwater levels (minimizing the overall root mean square, RMSE of groundwater level). Total 1500 model evaluations were generated for identifying optimal values of thirteen calibration parameters (table 3 ). The balance optimal values of the model parameters were selected by plotting the RMSE values of runoff and ground water level (figure 8), and selecting the model parameters for the run (out of 1500 model evaluation) representing the balanced minimal RMSEs of both the objective functions.

In table 3 , the calibrated value of $C_{\text {int }}=$ $0.04 \mathrm{~mm}$, indicates that a maximum $0.04 \mathrm{~mm}$ water would be retained in the interception storage (on vegetation), while $\mathrm{ET}$ surface depth $=1.53 \mathrm{~m}$, (shows the thickness of capillary fringe), signifies the clay content in soil of Yerli sub-catchment; and $D_{s}=2.09 \mathrm{~mm}$ represents the amount of depression storages over the ground surface. In unsaturated zone, $\theta_{s}=0.44$ indicates maximum water available in the root zone for evapotranspiration and percolation, whereas $\theta_{f_{c}}=0.33$ indicates the maximum water content available in the root zone to meet the vegetative evapotranspiration requirements, $\theta_{w p}=0.20$ specifies the limit of water content in unsaturated zone up to which the plants can extract the moisture from the soil without wilting, $K_{s}=1.93 \times 10^{-7} \mathrm{~m} / \mathrm{s}$ indicate low hydraulic conductivity of soil in the catchment due to dominant agriculture land and excessive clay content in the unsaturated zone. For saturated zone, lower calibrated values of $K_{x x}\left(=1.98 \times 10^{-5} \mathrm{~m} / \mathrm{s}\right)$ and $K_{y y}\left(=1.71 \times 10^{-6} \mathrm{~m} / \mathrm{s}\right)$ indicates the presence of low permeable alternate bed layers like clay and bare rocks in the major part of the catchment.
The parameters $D_{D}$ and $D_{T}$ are used to simulate routing of drainage water from saturated zone. The standard values of $D_{D}$ and $D_{T}$ are $1 \mathrm{~m}$ below ground surface and $1 \times 10^{-6} \mathrm{~s}^{-1}$, respectively (DHI 2017). The $D_{D}$ influences the recession part of discharge hydrograph, while $D_{T}$ determines the velocity of the drainage water from saturated zone. Higher values of $D_{D}$ and $D_{T}$ indicate larger contribution from base flow and higher drainage velocity (i.e., large peak), respectively. The calibrated drainage depth $\left(D_{D}=1.4 \mathrm{~m}\right)$ and drainage time constant $\left(D_{T}=10^{-7} \mathrm{~s}^{-1}\right)$ indicate moderate influence of base flow in stream runoff and slow drainage velocity, due to relatively shallow water table depth near the bank of Purna river and larger clay content in the soil.

\section{Results and discussion}

Sensitivity of thirteen model parameters has been demonstrated, by varying their values in wide range $( \pm 50 \%)$ and quantifying their influence on generated outputs, i.e., stream flows and groundwater levels. Also, the performance of calibrated model for optimal parameters, has been assessed using split-sampling procedure in prediction of stream flows and groundwater levels in the observation wells. Finally, the simulated water balance of the study area is discussed for both calibration and validation periods.

\subsection{Sensitivity analysis of model parameters}

In order to assess the importance of model parameters in generating the model output, sensitivity analysis of the model parameters was undertaken by changing the values of the model 
Table 3. Model parameters for simulation of stream flow for Yerli sub-catchment.

\begin{tabular}{|c|c|c|c|c|c|}
\hline Component & Parameters & Unit & Range & $\begin{array}{c}\text { Initial } \\
\text { value }\end{array}$ & $\begin{array}{l}\text { Calibrated } \\
\text { value }\end{array}$ \\
\hline \multicolumn{6}{|l|}{ ET zone } \\
\hline \multirow[t]{4}{*}{ Vegetation } & $\begin{array}{l}\text { Leaf Area Index (LAI) } \\
\text { (average based on } \\
\text { land use) }\end{array}$ & - & 5.00 & $5.00^{*}$ & - \\
\hline & $\begin{array}{l}\text { Root Depth (RD) } \\
\text { (average based on } \\
\text { land use) }\end{array}$ & $\mathrm{mm}$ & 986.00 & $986.00^{*}$ & - \\
\hline & $C_{\text {int }}$ & $\mathrm{mm}$ & $0.01-0.1$ & 0.01 & 0.04 \\
\hline & ET surface depth & $\mathrm{m}$ & $0.10-2.00$ & 1.00 & 1.53 \\
\hline \multicolumn{6}{|c|}{ Surface zone and stream channel } \\
\hline Surface roughness & Manning's $M$ & $\mathrm{~m}^{-1 / 3} \mathrm{~s}$ & $6.67-35.71$ & Table $2^{*}$ & - \\
\hline Storage & Detention storage $\left(D_{\mathrm{s}}\right)$ & $\mathrm{mm}$ & $0.00-5.00$ & 0.50 & 2.09 \\
\hline Channel roughness & Manning's $n$ & $\mathrm{~m}^{-1 / 3} \mathrm{~s}$ & 0.03 & 0.03 & - \\
\hline \multicolumn{6}{|l|}{ Unsaturated zone } \\
\hline \multirow[t]{4}{*}{ Soil } & $\begin{array}{l}\text { Moisture content at } \\
\text { saturation }\left(\theta_{s}\right)\end{array}$ & - & $0.40-0.60$ & 0.40 & 0.44 \\
\hline & $\begin{array}{l}\text { Moisture content at } \\
\text { field capacity }\left(\theta_{f_{c}}\right)\end{array}$ & - & $0.20-0.45$ & 0.20 & 0.33 \\
\hline & $\begin{array}{l}\text { Moisture content at } \\
\text { wilting point }\left(\theta_{w p}\right)\end{array}$ & - & $0.10-0.25$ & 0.10 & 0.20 \\
\hline & $\begin{array}{c}\text { Saturated hydraulic } \\
\text { conductivity }\left(K_{s}\right)\end{array}$ & $\mathrm{m} / \mathrm{s}$ & $1 \times 10^{-8}-1 \times 10^{-5}$ & $1 \times 10^{-6}$ & $1.93 \times 10^{-7}$ \\
\hline \multicolumn{6}{|l|}{ Saturated zone } \\
\hline \multirow{6}{*}{$\begin{array}{l}\text { Hydro-geological layer } \\
(33-200 \mathrm{~m} \text { below } \\
\text { ground level (bgl)) }\end{array}$} & $\begin{array}{c}\text { Horizontal hydraulic } \\
\text { conductivity }\left(K_{x x}\right)\end{array}$ & $\mathrm{m} / \mathrm{s}$ & $1 \times 10^{-7}-1 \times 10^{-3}$ & $1 \times 10^{-4}$ & $1.98 \times 10^{-5}$ \\
\hline & $\begin{array}{l}\text { Vertical hydraulic } \\
\text { conductivity }\left(K_{y y}\right)\end{array}$ & $\mathrm{m} / \mathrm{s}$ & $1 \times 10^{-8}-8 \times 10^{-5}$ & $1 \times 10^{-7}$ & $1.71 \times 10^{-6}$ \\
\hline & Specific yield $\left(S_{y}\right)$ & - & $0.10-0.30$ & 0.1 & 0.12 \\
\hline & Storage coefficient $\left(S_{c}\right)$ & - & $0.00001-0.001$ & 0.00001 & 0.00045 \\
\hline & Drainage depth $\left(D_{D}\right)$ & $\mathrm{m}$ bgl & $0.5-1.5$ & 0.5 & 1.4 \\
\hline & Drainage time constant & $\mathrm{s}^{-1}$ & $1 \times 10^{-8}-1 \times 10^{-5}$ & $1 \times 10^{-7}$ & $1 \times 10^{-7}$ \\
\hline
\end{tabular}

*Parameters were estimated based on existing physiography of the sub-catchment.

parameters up to $\pm 50 \%$ of their optimal values (attained through auto-calibration), and the simulated runoff and groundwater levels with reference were compared to the simulated outputs of optimal model parameters for the data of years 19911998 at Yerli stream gauging station. The variation in runoff volume, peak runoff and mean groundwater levels were used to evaluate their sensitivity with percentage variation in the MIKE SHE model parameters (table 4 ).

From table 4 , it is revealed that parameters $\theta_{s}, \theta_{f c}$, and $K_{x x}$ have significant influence on runoff volume, generating peak runoff at catchment outlet and groundwater level within the catchment. While changing the value of $\theta_{s}$ (moisture content at saturation) in the range of -50 to $+50 \%$ with reference to its calibrated value, the corresponding variations in \% runoff volume, peak runoff and mean groundwater level are 12.9 to $-20.60,14.65$ to -23.9 , and -18.62 to $21.50 \%$, respectively. The increase in saturation water content of soil $\left(\theta_{s}\right)$ leads to higher storage of groundwater reserve in saturated porous media, and, consequent, reduction in peak runoff, runoff volume and increase in groundwater levels. Further, variation in $\theta_{f c}$ values from +50 to $-50 \%$ causes -25.62 to $27.11 \%$ variations in runoff volume, -27.11 to $35.60 \%$ in peak runoff, and 14.69 to $-15.26 \%$ variations in mean groundwater level. The influence of field capacity $\left(\theta_{f c}\right)$ is similar to saturation moisture capacity of soil due to holding up of large volume of water in unsaturated porous media and, consequently, reduction in volume of runoff and peak runoff. The higher $\theta_{f c}$ 


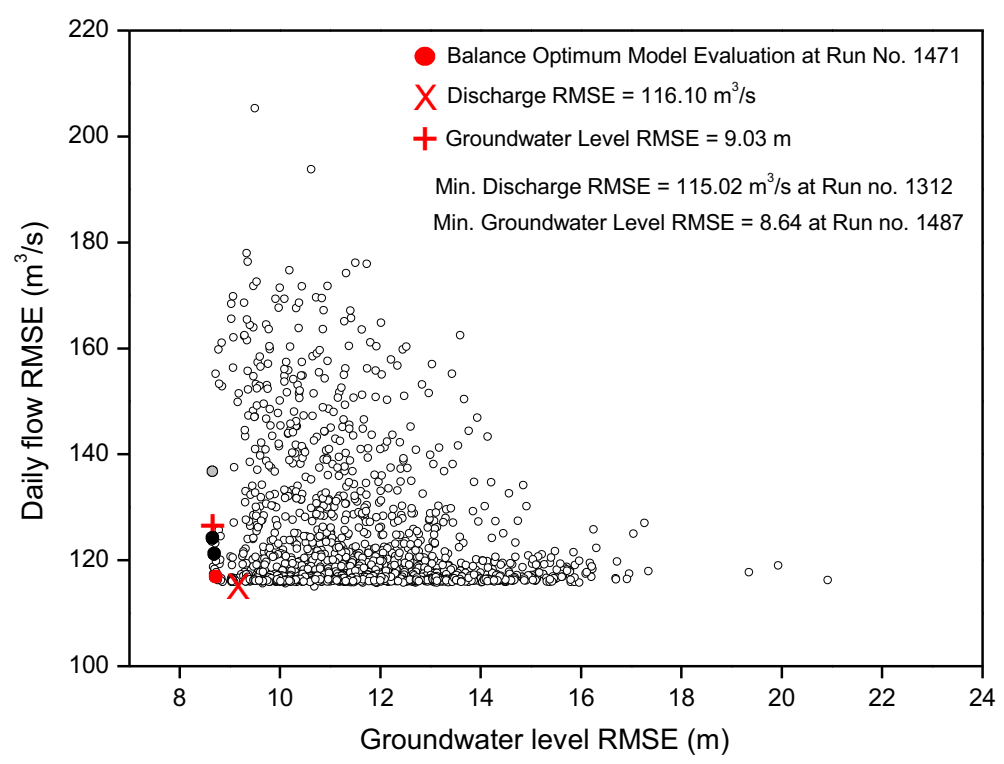

Figure 8. Selection of optimal parameters from auto-calibration results using multi-objective approach.

values may suffice in meeting the transpiration requirement of plants, leading to relatively less extraction of groundwater, and, hence, attributed to higher groundwater table in the study region. The horizontal hydraulic conductivity $K_{x x}$ causes variation from -32.00 to $10.40 \%$ in runoff volume, -39.00 to $16.80 \%$ in peak runoff and 14.40 to $12.90 \%$ in groundwater level while changing its optimal value from -50 to $+50 \%$. As expected, a decrease in $K_{x x}$ causes slow movement of water, more storage of water within the porous media, and, thereof, low peak as well as runoff volume at the catchment outlet and leading to higher groundwater levels within the sub-catchment. The ET surface depth has moderate influence on runoff volume, peak runoff and mean groundwater level wherein by varying its values in the range of +50 to $-50 \%$ with reference to its calibrated value, percentage variation in runoff volume, peak runoff and mean groundwater level have been observed to be in the range of -4.97 to 4.50 , -3.40 to 4.10 , and -2.49 to $3.06 \%$, respectively (see table 4). A higher value of ET depth yields lesser runoff due to extraction of more water from plants and vegetation via their root zones to meet evapotranspiration needs. Furthermore, variation of $K_{s}$ parameter in the defined range $(+50$ to $-50 \%)$ causes variations of -8.70 to $6.70 \%$ in runoff volume, -19.10 to $7.60 \%$ in peak runoff and 0.45 to $-4.60 \%$ in average groundwater level. The increase in $K_{s}$ value with reference to its calibrated (optimal value) causes reduction in volume of runoff and peak runoff as higher $K_{s}$ values means large infiltration rate, and, reduction in water available for surface runoff, and causes slight increase in groundwater level. The $K_{y y}$ parameter has been observed to have moderate influence on runoff volume from -7.40 to $4.20 \%,-6.20$ to $5.50 \%$ on peak runoff and 1.5 to $-0.70 \%$ on average groundwater level while varying its value in the range of +50 to $-50 \%$ with reference to its calibrated value. The influence of $K_{y y}$ is similar to $K_{s}$ parameter on volume of runoff, peak runoff, and groundwater levels, as former also causes the movement of water in vertical direction in the saturated porous media/groundwater. The $D_{s}$ and $\theta_{w p}$ parameters have less influence on runoff volume, peak runoff and mean groundwater levels. The other parameters including $C_{\text {int }}$, $S_{y}, S_{c}, D_{D}$ and $D_{T}$ have negligible influence on volume of runoff and peak runoff. Low sensitivity of $C_{\text {int }}$ may be due to the low proportion of precipitation as canopy storage. The $C_{\text {int }}$ during the low precipitation period may become significant parameter when canopy storage fraction is large with reference to total precipitation. The low sensitivity of model with reference to specific yield and storage coefficient, possibly due to consideration of lumped value of geological parameters in the saturated zone. In present study, Manning's $M$ values for overland flow were selected based on land use/cover pattern of the catchment, and using their corresponding information available in the literature (Vieux 2001; Kothyari et al. 2010; Keilholz et al. 2015). The influence of distributed Manning's roughness coefficient vis-à-vis its lumped values in generating runoff is described in subsection 4.2 . 


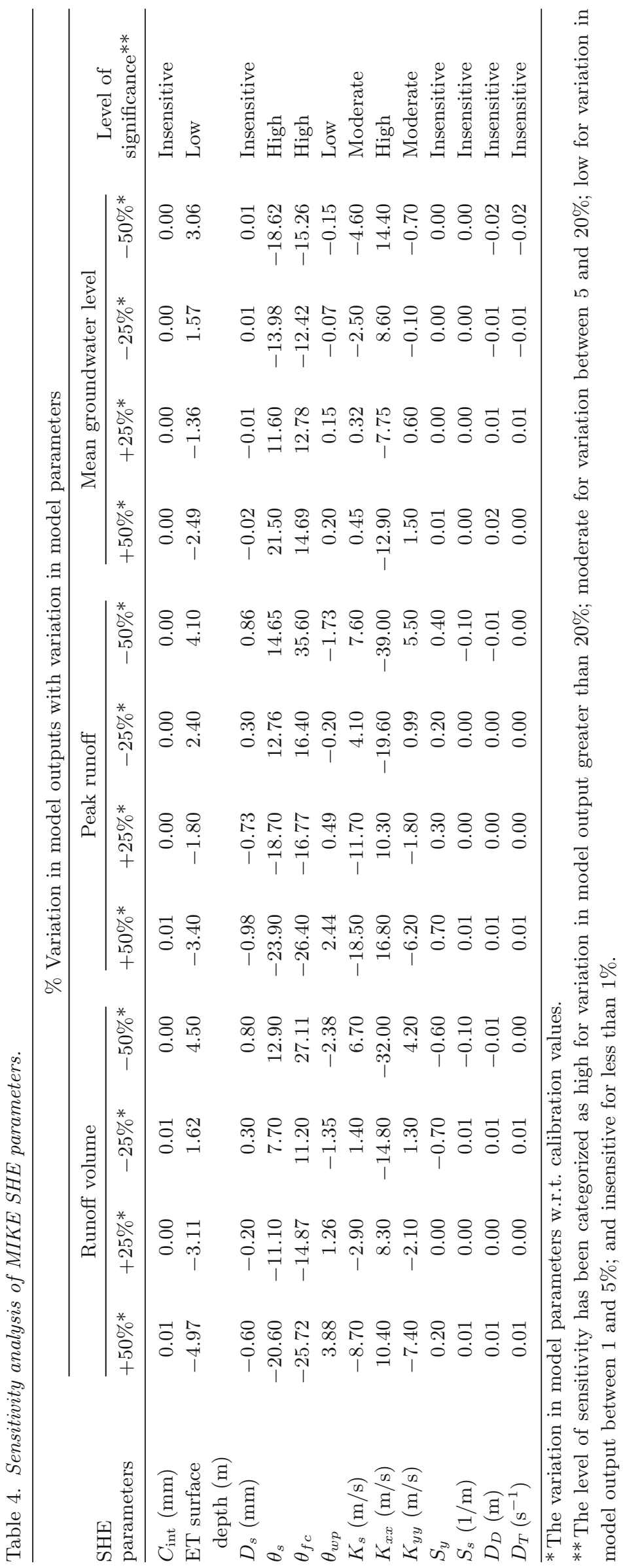


4.2 Impact of lumped vs. distributed Manning's $M$ on stream runoff

The Manning's $M$ has been found to be significant parameter in modelling overland flow while using 2D diffusive wave finite difference approximation in Saint Venant's equations (Chow et al. 1988). Initially, the daily stream flows of Yerli subcatchment for duration 1991-1998, were simulated using single value (lumped global value) of Manning' $M$, and optimally calibrated values of other parameters defined in table 3. The RMSEs of simulated vs. observed daily discharges and average groundwater levels, were found to be $164.23 \mathrm{~m}^{3} / \mathrm{s}$ and $15.67 \mathrm{~m}$, respectively. Subsequently, the distributed Manning's $M$ values, depending upon land use/land cover of the sub-catchment, and selected from literature (Chow et al. 1988; Vieux 2001; Kothyari et al. 2010; Keilholz et al. 2015) was utilised, in place of its lumped value for simulation of flow of the same period (1991-1998). The performance of the model has been found to improve significantly (RMSE of $116.10 \mathrm{~m}^{3} / \mathrm{s}$ and $9.03 \mathrm{~m}$ for daily discharges and average ground water levels, respectively) while using distributed Manning's $M$ vis-à-vis lumped values within the catchment. Thus, aforesaid analyses clearly suggest that hydrological processes are dominantly affected by the heterogeneity of surface roughness within the catchment. Also, the analysis of Vo and Gourbesville (2016), reported significant impact of Manning's roughness coefficient on overland flow computation in the catchment. The results reported in following sub-sections include the simulation of hydrological processes using distributed Manning's $M$ within the catchment.

\subsection{Validation of calibrated model using split sampling procedure}

\subsubsection{Prediction of stream flow}

The performance of the MIKE SHE/MIKE 11 model under calibration stage for years 1991-1998 in terms of hydrographs on daily and monthly time scales, runoff volume and flow duration curves are depicted in figure 9. The performance of model is also quantified using statistical performance indices such as MAE, RMSE, $r$, NSE, and EI for observed and simulated flows. In table 5, RMSE (116.26 m³ $/ \mathrm{s}), r(0.80)$ and NSE (0.65) indicate good agreement between observed and simulated daily flow discharge with slight under prediction of peak discharges on daily time scale (figure $9 \mathrm{a}$ and $\mathrm{b}$ ).

The performance of calibrated hydrological model has also been assessed for simulation of stream flows at the outlet of Yerli sub-catchment using independent data (split sampling) for period year 1999-2004. The simulated runoff at daily and monthly time scales were generated using MIKE SHE model, and routed through the river network using MIKE 11 to obtain the simulated stream flows at Yerli stream gauging station. The daily/monthly flows using calibrated model has been compared with corresponding observed flow parameters (figure 10a-c). The statistical performance indices, viz., RMSE $\left(114.79 \mathrm{~m}^{3} / \mathrm{s}\right), r(0.86)$ and NSE (0.70), exhibit good agreement between observed and simulated daily flow discharges for years 1999 and 2002 (table 5). The observed and simulated flows during calibration and validation periods (figures $9 \mathrm{a}-\mathrm{d}$ and $10 \mathrm{a}-\mathrm{d}$ ), revealed that peak flows, invariably, are under predicted by the calibrated model while lean period flows are over predicted for both calibration and validation periods. The simulated hydrographs compare well with the observed hydrographs particularly at monthly time scale. Also, it is pertinent to mention that cumulative simulated runoff during the monsoon period (June-September) is consistently lower than monthly observed runoff at catchment outlet. The trend is reversed for the lean period in simulating the stream flows for both calibration and validation periods (figures 9d and 10d). Such discrepancies in the prediction of stream flows are attributed to (a) consideration of semi-distributed rainfall input using Thiessen polygon approach instead of using gridded rainfall input, (b) consideration of oneD flow model in unsaturated porous media, i.e., entire water goes in recharging the groundwater, and there is not any contribution in the flow as interflow, and (c) consideration of lumped parameters in saturated porous media which may lead to excessive delay in base flow contribution in the stream during the lean period.

In figures 9 and 10(e and $\mathrm{f}$ ), the stream flows at outlet of the sub-catchment are classified as low flows $\left(>Q_{50}\right)$, medium flows $\left(Q_{10}-Q_{50}\right)$ and high flows $\left(<Q_{10}\right)$ for dependable flows $>50,50$ 10 and $<10 \%$, respectively (Clausen and Biggs 2000; Swain and Patra 2017). The higher value of EI (0.96 for daily and 1.00 for monthly) indicates better simulation of the flow duration curve at monthly and daily time scales. While comparing observed and simulated dependable flows 

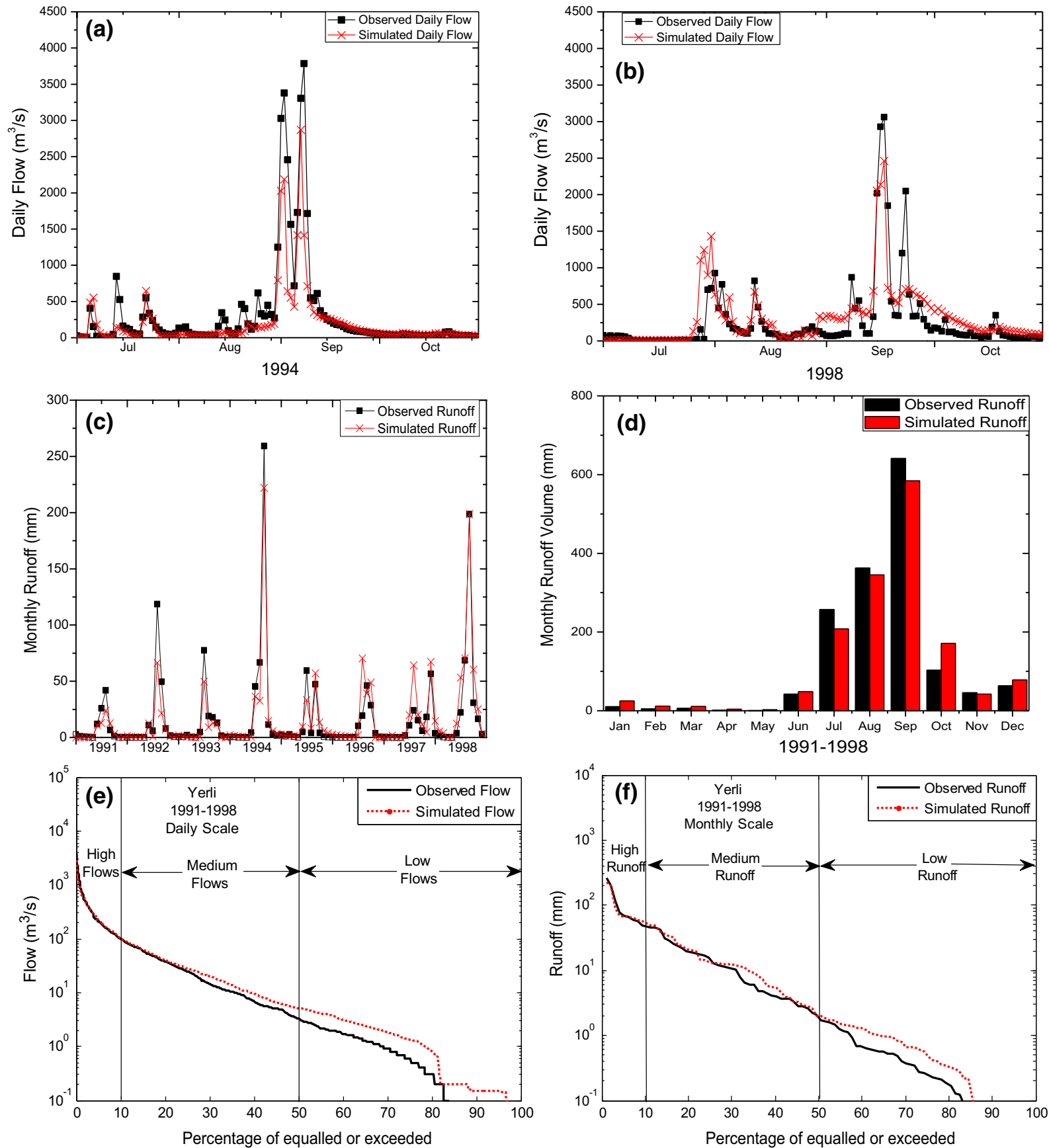

Figure 9. Performance of calibrated hydrological model in terms of observed and simulated (a) hydrograph for year 1994, (b) hydrograph for year 1998, (c) hydrograph for years 1991-1998 at monthly scale, (d) month-wise cumulative volume of runoff for period 1991-1998, (e) flow duration curve on daily scale for period of 1991-1998, and (f) flow duration curve at monthly scale for period 1991-1998.

Table 5. Model performance indicators during calibration and validation.

\begin{tabular}{|c|c|c|c|c|c|c|c|c|c|c|c|}
\hline \multirow{2}{*}{$\begin{array}{l}\text { Stream } \\
\text { gauging } \\
\text { site }\end{array}$} & \multirow[b]{2}{*}{$\begin{array}{l}\text { Time } \\
\text { period }\end{array}$} & \multicolumn{5}{|c|}{ Daily } & \multicolumn{5}{|c|}{ Monthly } \\
\hline & & $\begin{array}{l}\text { MAE } \\
\left(\mathrm{m}^{3} / \mathrm{s}\right)\end{array}$ & $\begin{array}{l}\text { RMSE } \\
\left(\mathrm{m}^{3} / \mathrm{s}\right)\end{array}$ & $r$ & NSE & EI & $\begin{array}{l}\text { MAE } \\
(\mathrm{mm})\end{array}$ & $\begin{array}{r}\text { RMSE } \\
(\mathrm{mm})\end{array}$ & $r$ & NSE & EI \\
\hline \multirow[t]{2}{*}{ Yerli } & 1991-1998 & 43.21 & 116.26 & 0.80 & 0.66 & 0.96 & 6.59 & 12.89 & 0.93 & 0.85 & 1.00 \\
\hline & 1999-2004 & 33.69 & 114.79 & 0.86 & 0.70 & 0.89 & 3.21 & 8.09 & 0.95 & 0.89 & 0.89 \\
\hline
\end{tabular}



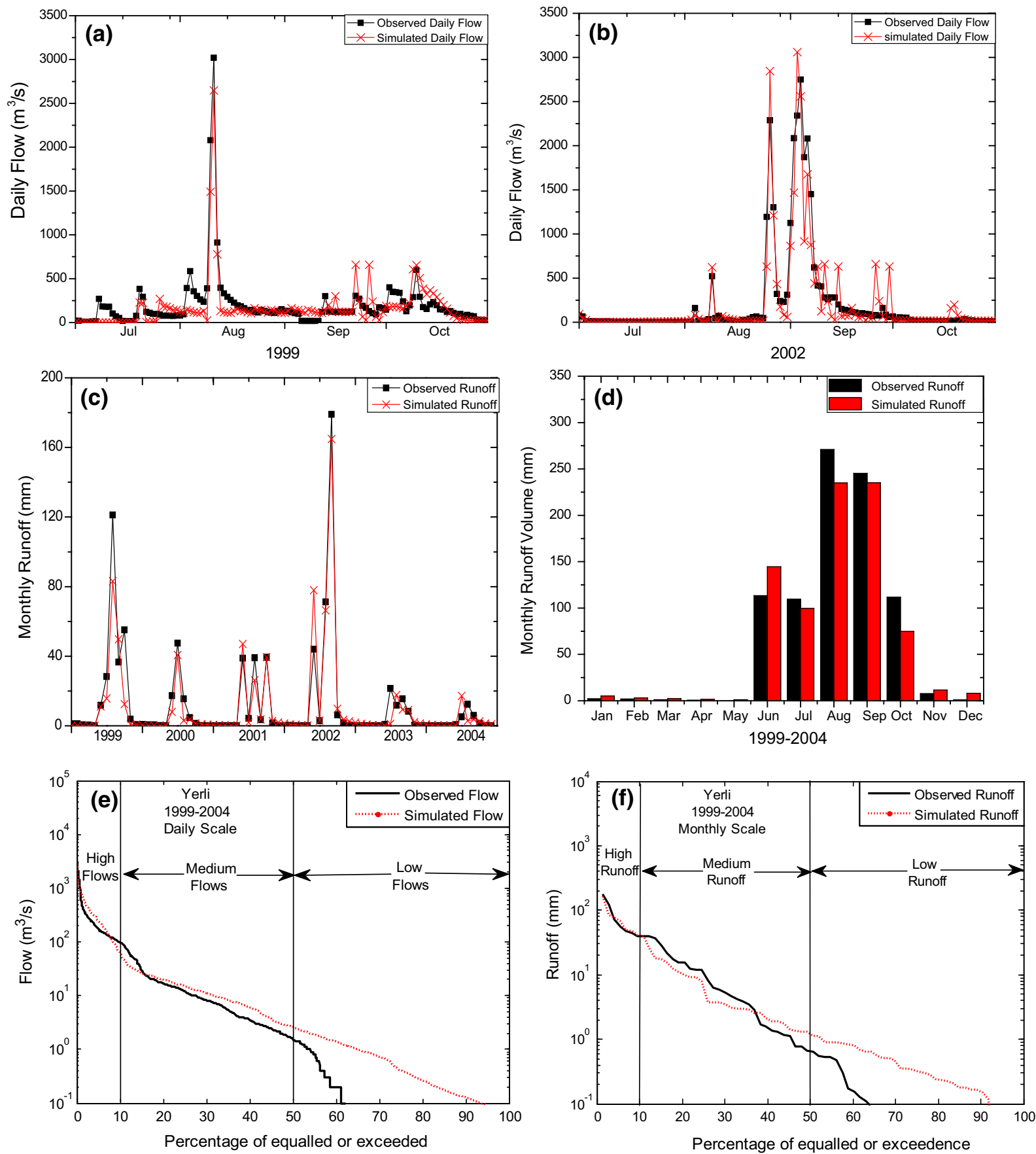

Figure 10. Performance of calibrated hydrological model in terms of observed and simulated (a) hydrograph for year 1999, (b) hydrograph for year 2002, (c) hydrograph for years 1999-2004 at monthly scale, (d) month-wise cumulative volume of runoff for period 1999-2004, (e) flow duration curve on daily scale for period of 1999-2004, and (f) flow duration curve at monthly scale for period 1999-2004.

for calibration (figure $9 \mathrm{e}$ and $\mathrm{f}$ ) and validation period (figure $10 \mathrm{e}$ and $\mathrm{f}$ ), it is indicated the model simulate satisfactorily high and medium flows $(<50 \%$ dependable flow) vis-à-vis low flows ( $>50 \%$ dependable flow). The low stream flows $<1.0 \mathrm{~m}^{3} / \mathrm{s}$ have been simulated on higher side vis-à-vis observed flow conditions in the same range. Such discrepancy is ascribed to the artefact of MIKE SHE/MIKE 11 that does not allow for a river/stream to dry out during the drier periods (Dai et al. 2010; Wang et al. 2012). Further, the hydrological models can be acceptable as useful within quantitative performance bounds, i.e., $\%$ water balance $(\% \mathrm{WBL})<10 \%$, NSE $>0.65$, and $r>0.75$ (Refsgaard and Knudsen 1996; Lorup et al. 1998; Wang et al. 2012). Hence, presented 

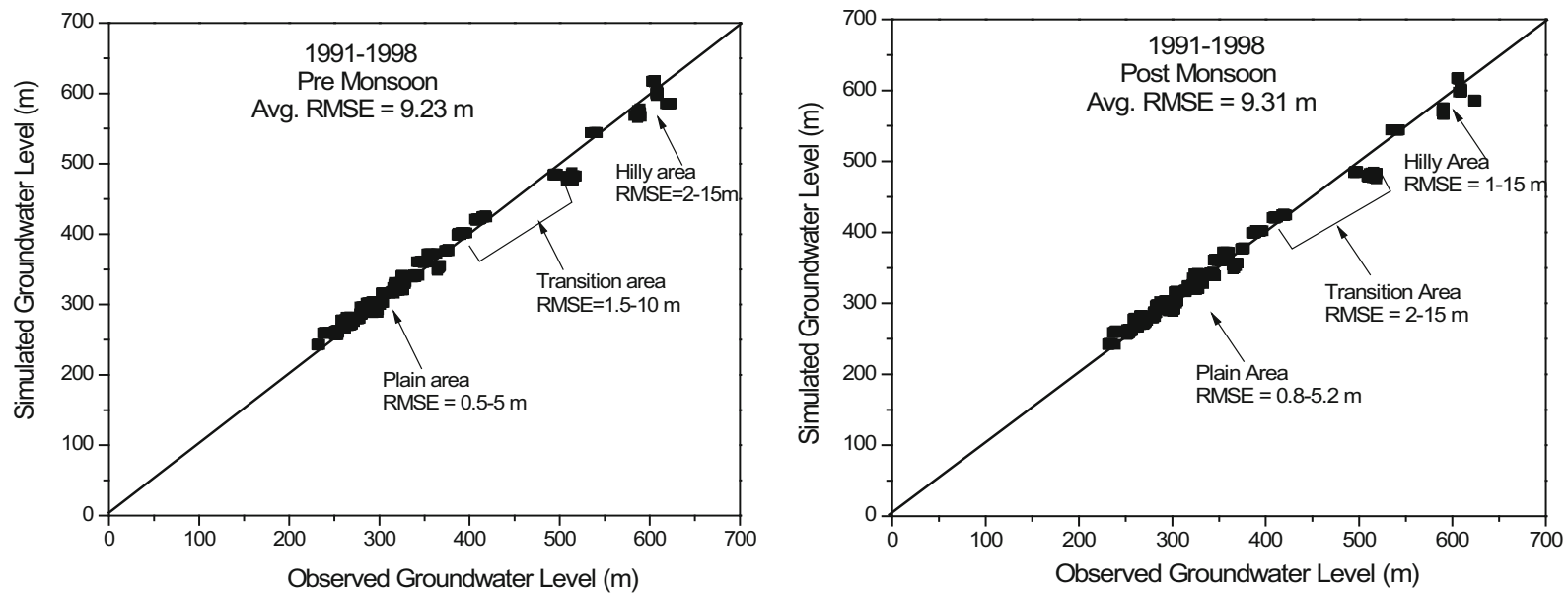

Figure 11. Comparison of observed groundwater levels with simulated groundwater levels for pre- and post-monsoon season during 1991-1998.
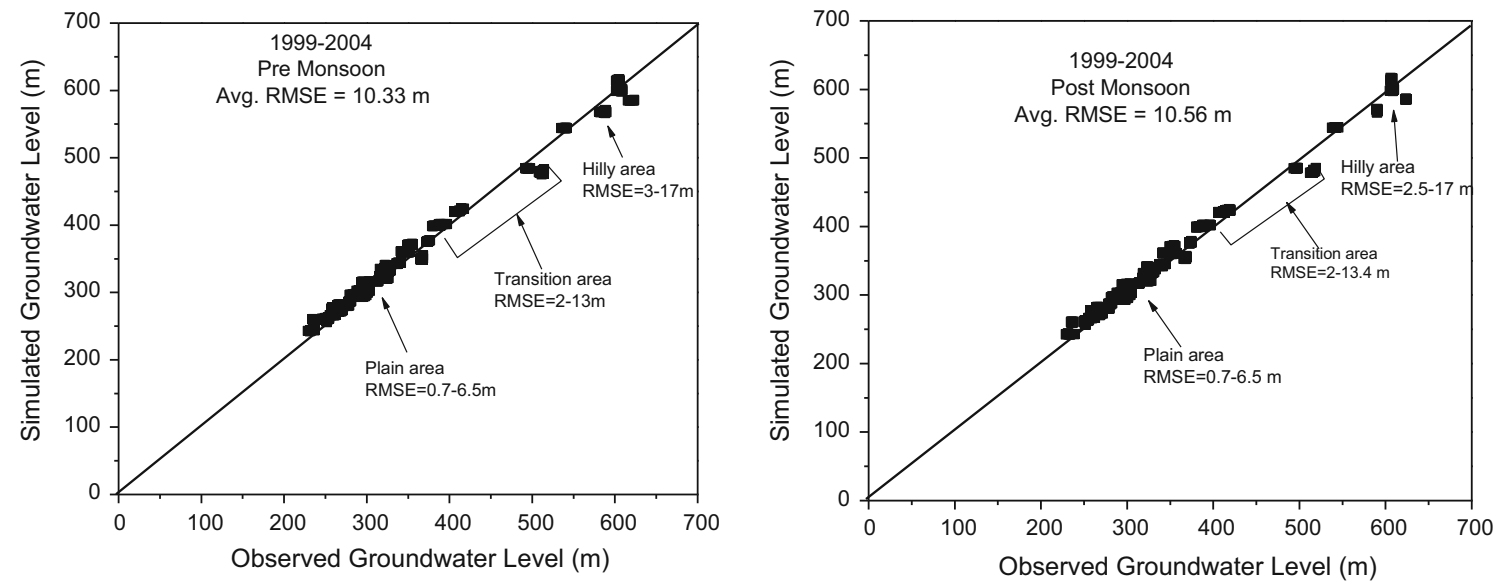

Figure 12. Comparison of observed groundwater levels with simulated groundwater levels for pre- and post-monsoon season during 1999-2004.

results are within the acceptable limits for understanding the components of hydrological cycle of semi-arid catchment.

\subsubsection{Prediction of groundwater levels}

The data of 49 observation wells in the study region were used for calibration of the model for period 1991-1998. The performance of the model has been assessed using the pre-monsoon (January and May) and post-monsoon (August and November) observations within the Yerli subcatchment. The performance of the model in prediction of groundwater levels during calibration and validation periods are shown in figures 11 and 12 , respectively. Invariably, the simulated groundwater levels are predicted satisfactorily for plain area $(\mathrm{RMSE}=0.5-5 \mathrm{~m})$ vis-à-vis simulated values in the transition and hilly areas (RMSE $=$
$1.5-10 \mathrm{~m}$ for transitional area, and $\mathrm{RMSE}=2-15$ $\mathrm{m}$ for hilly area). Similar, performance from the model has been obtained for validation period as RMSEs of observed and simulated groundwater levels vary from 0.7 to $6.5,2$ to 13.4 and 2.5 to $17 \mathrm{~m}$, respectively for plain, transitional and hilly areas (figure 12). The continuous simulation of groundwater levels in all 49 ob servation wells indicate the trend of groundwater table in the study region for period 1986-2004 (figure 13).

From figure 13, it is seen that performance of the model in prediction of groundwater level is similar in both calibration and validation periods for the wells in the sub-catchment. As reported above, it is clearly revealed that simulated groundwater table in the plain area (ground level $<378 \mathrm{~m}$ ) is simulated better than transitional areas (ground levels 378-500 m) and hilly areas (ground level $>500 \mathrm{~m}$ ). Such discrepancies in the prediction of 
Tृ:
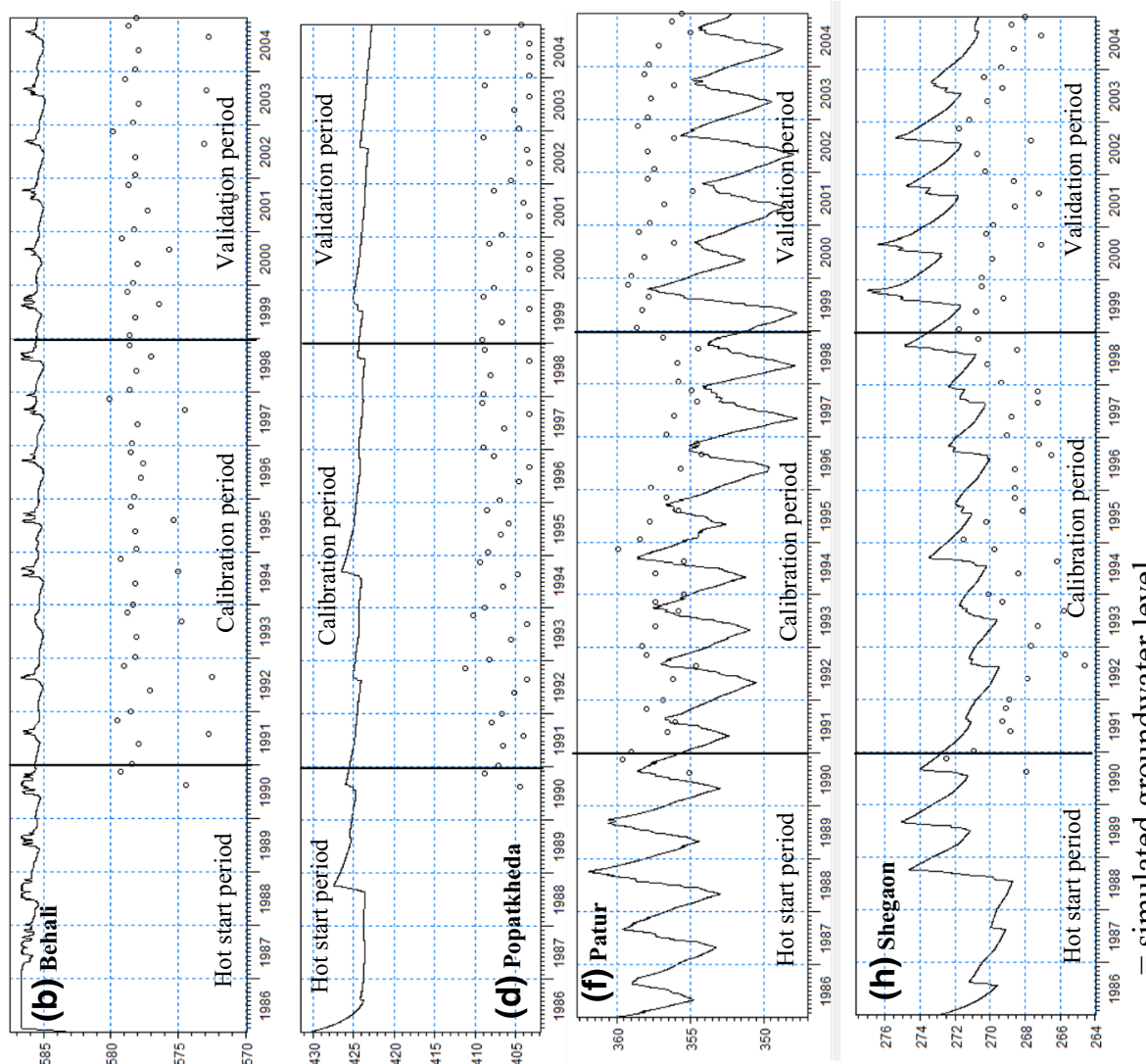

6

कृ 5

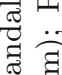

굴

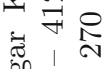

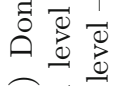

త్)

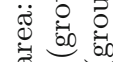

융 శี

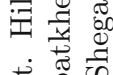

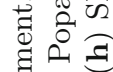

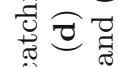

旅

:

$\therefore \frac{1}{1} \frac{1}{0}$
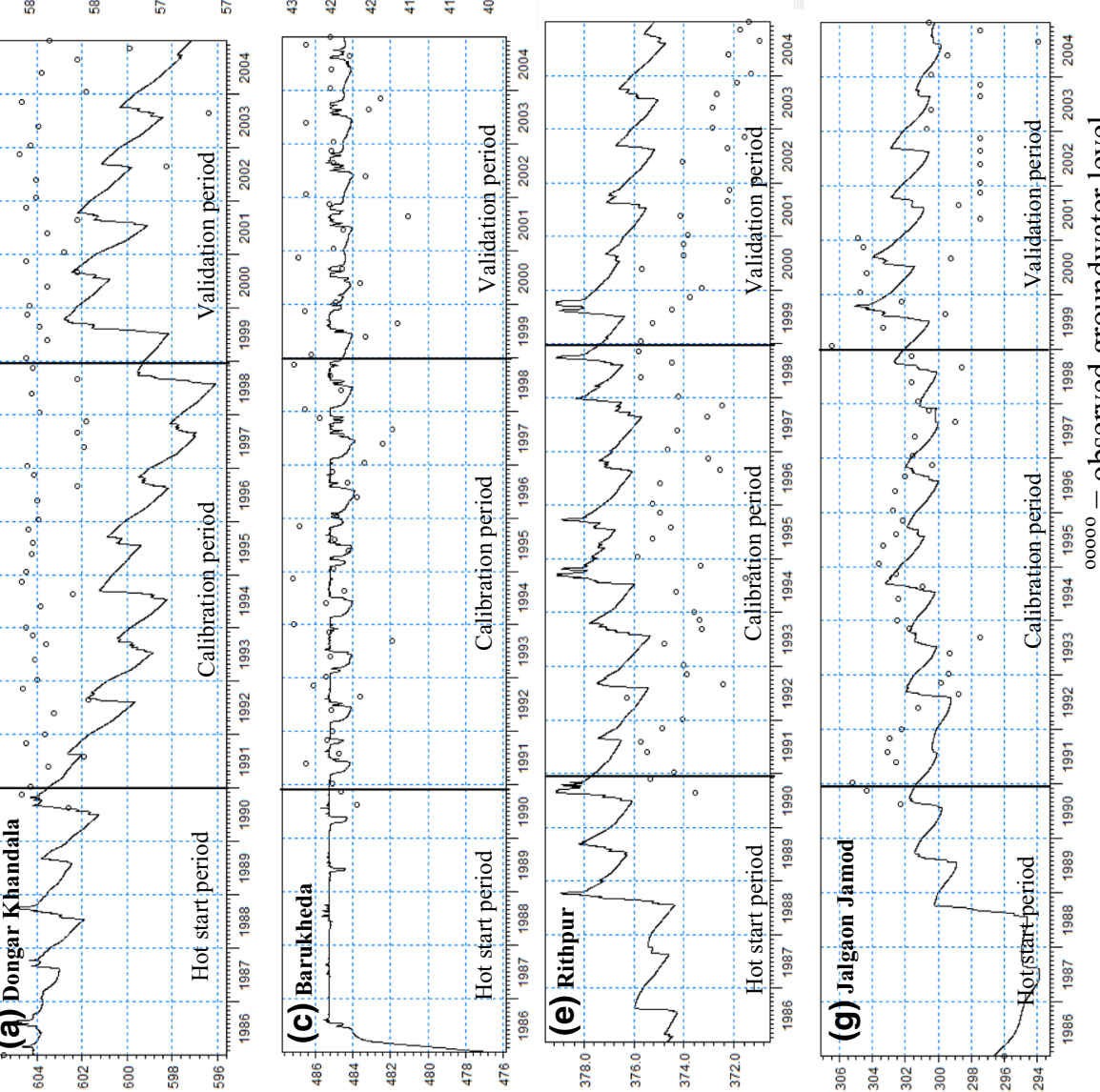

:

룽 곡

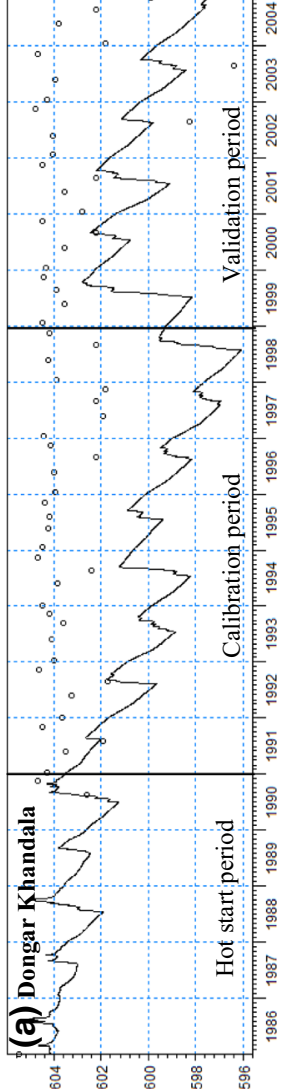

营莡

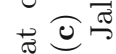

용

己

式胥离

密

总言焉克

क्.

臣 $\varnothing 0$

舀

胥总

范

品

능

ำ

范

豆宫递

$\dot{\rightarrow} \overrightarrow{8}: \vec{\Xi}$

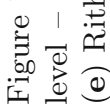




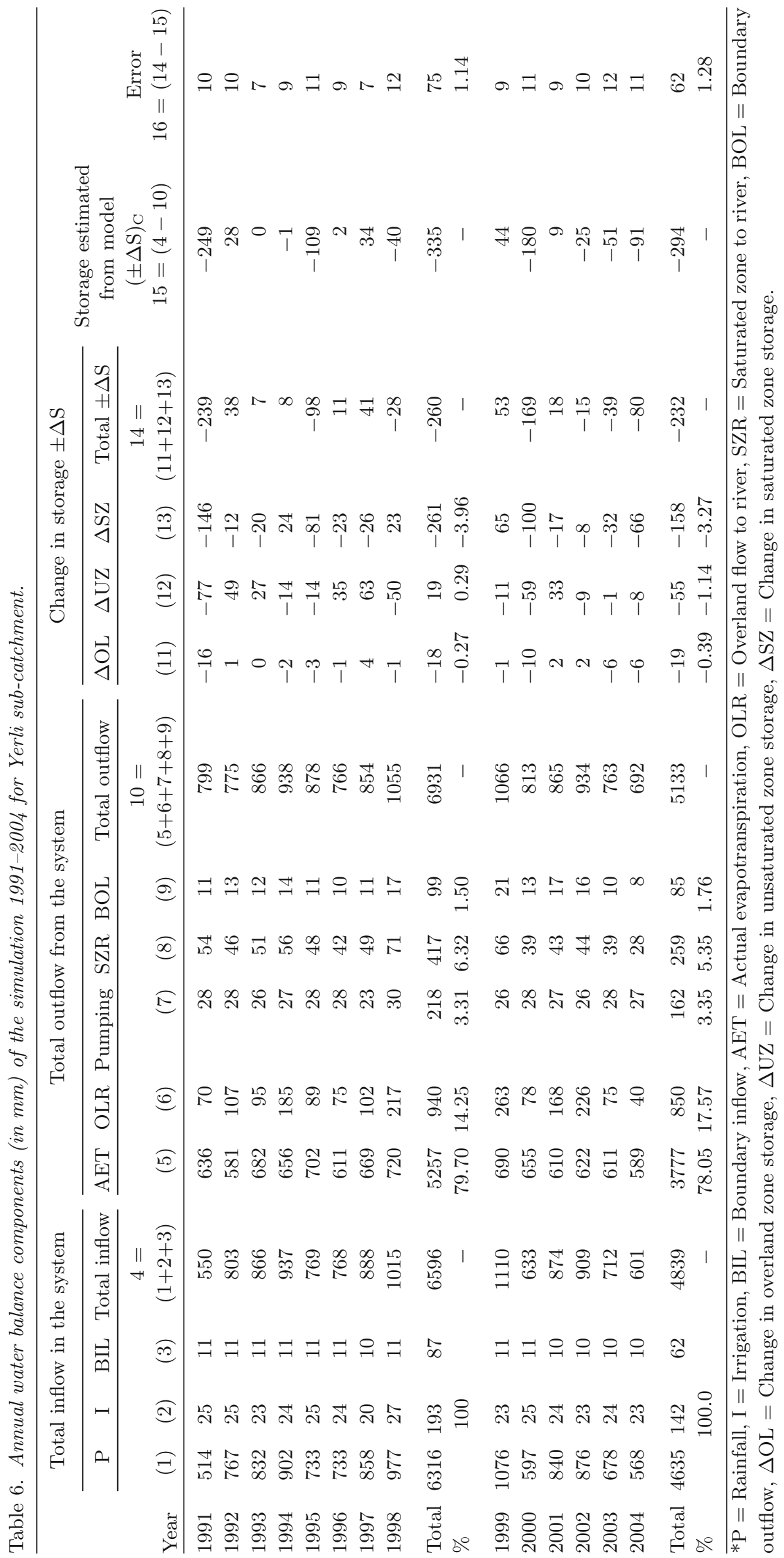



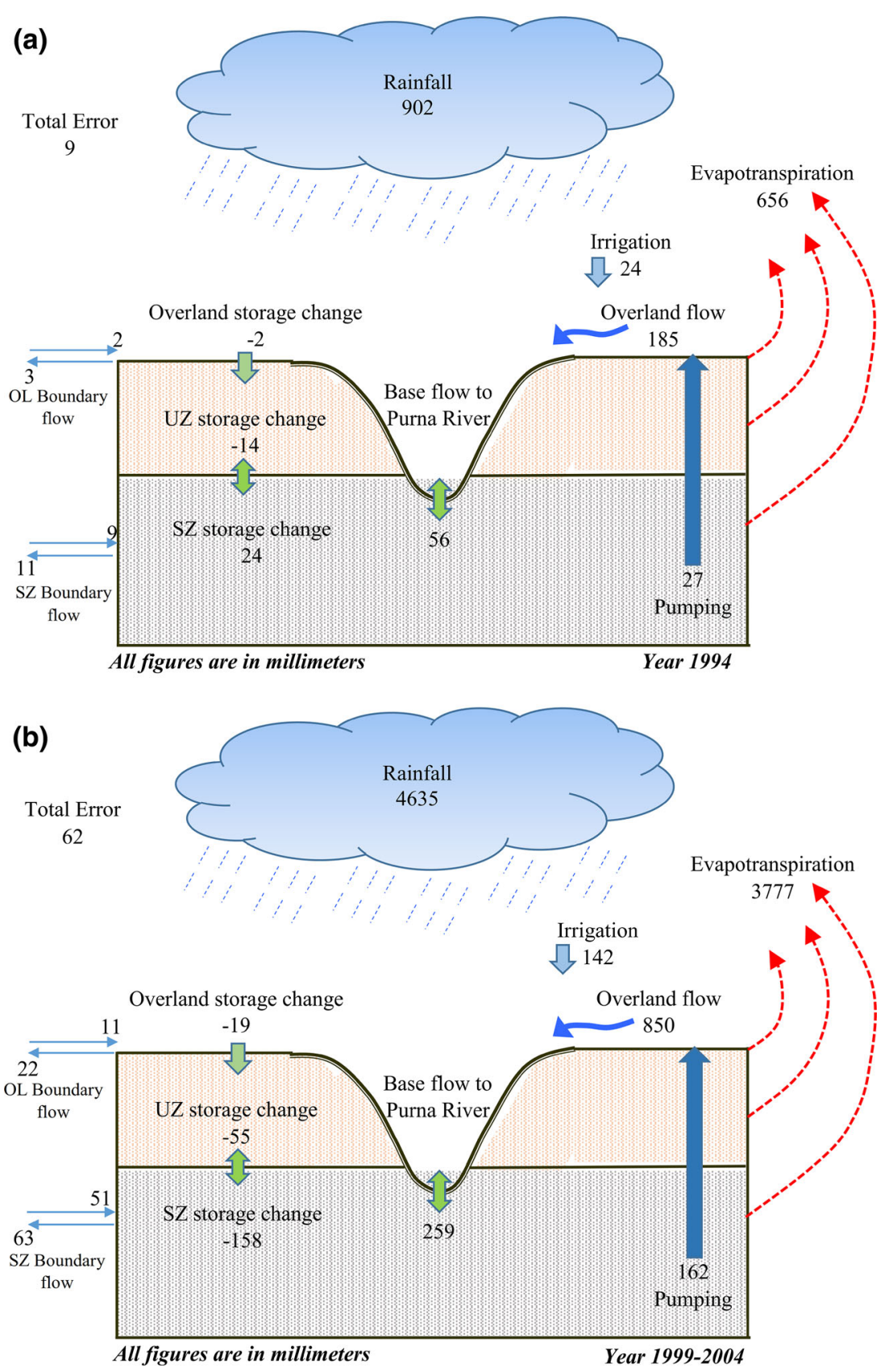

Figure 14. Simulated water balance of Yerli sub-catchment for (a) year 1994 and (b) year 1999-2004.

groundwater table, are due to (a) non-availability of detailed information about actual wells being operated in agriculture fields, village and urban centres. As stated earlier, the location of wells in the model are incorporated at the centre of each tehsil for irrigation wells; and village/urban centres for domestic/industrial wells. The interference effects of actual wells (i.e., effects of cone of depression of one well on others) in the study region may be different from the simulated wells taken in the present study, (b) simulated groundwater levels indicate the values at the centre of the model grids, whereas actual observation may be located away from the grid centres, (c) model is not able to account for the local heterogeneity at the scale smaller than the model grid size, (d) consideration of one-D flow conditions in unsaturated zone, may not be applicable for hilly/transitional areas due to large variations in elevation at spatial scales and heterogeneity in terms of soil and aquifer characteristics, (e) implementation of 2-layer water balance approach, invariably gives better performance in shallow water table conditions in the plain areas. As stated earlier, Richard's equation was not implemented in present study due to extensive computational requirements in such 
large areas, and (f) consideration of lumped characteristics in the entire saturated zone with same values for shallow and deep aquifers.

\subsection{Water balance of Yerli sub-catchment}

Water balance is an important and essential result of the model simulation, which gives useful information on available water resources and their sustainable usage in the study area. Table 6 shows the annual water balance components (in unit $\mathrm{mm}$ ) of the entire Yerli sub-catchment system for the whole simulation period. The main components included in the simulated water balance from the model are, inflows into the system (precipitation + irrigation + boundary inflows), outflows (actual evapotranspiration + overland flow to river + saturated flow to river + groundwater pumping + boundary outflows) from the system and changes in storages (overland zone change + unsaturated zone change + saturated zone change) of the system (figure 14). Overall during 1991-1998, the total simulated inflow is $6596 \mathrm{~mm}$ while the total outflow is $6931 \mathrm{~mm}$. The deficit, i.e., $260 \mathrm{~mm}$ is balanced by storage depletion in overland flow and subsurface flow systems (i.e., unsaturated and saturated sub-systems). Similar trend is also observed during validation time 1999-2004 (table 6). Most of the water $(78 \%)$ entering into the system leaves through hydrological processes like evapotranspiration from overland zone, unsaturated zone, and saturated zone storages; while $3.5 \%$ leaves the system through groundwater pumping for irrigation as well as domestic and industrial supplies. The deficit indicated in water balance analysis is due to existence of drought conditions during the years 1991, 2000 and 2004 (figure 7). The high actual evapotranspiration during calibration $(79 \%$ of inflows and validation period $78 \%$ of inflows) is due to existence of extensive cropping low permeability of soil in the study area and typical climatic conditions of the semi-arid region. An effective approach to improve water use efficiency in the catchment reduce the actual ET, e.g., by introducing water saving technologies and changes in cropping pattern. Also, total surface runoff of about 14.25 and $17.57 \%$, in terms of rainfall, were simulated during 1991-1998 and 1999-2004, respectively, in the catchment. Generally, ground water table in the study area varies within 5 to $10 \mathrm{~m}$ below the ground surface (NBSS \& LUP 2008). This causes low base flow (SZ into river) of about $6.32 \%$ and of about $5.35 \%$ during calibration and validation periods, respectively, within the catchment. The calculated water balance errors are of the order 1.14 and $1.28 \%$ during calibration period (1991-1998) and validation period (1999-2004), respectively (table 6).

\section{Summary and conclusions}

The multi-objective optimization approach using shuffle complex evolution algorithm, has been used in prediction of optimal parameters of surface, unsaturated and saturated zones of MIKE SHE/ MIKE 11 coupled modelling system. The sensitivity of model outputs in terms of volume of runoff, peak flows and average groundwater levels has been quantified with reference to the model parameters. The performance of the model is demonstrated in prediction of stream flow, groundwater levels and water balance of independent period. The key conclusions from forgoing study is summarised as follows:

- The simulated volume of stream flows, peak flows and groundwater levels has been found to be highly sensitive with respect to saturation water content, field capacity and horizontal hydraulic conductivity of saturated porous media (table 4). On the other hand, vertical hydraulic conductivity of unsaturated and saturated porous media have moderate influence on generating aforesaid outputs.

- The calibrated model has been reported to predict satisfactorily, stream flows at Yerli catchment outlet $\left(\mathrm{RMSE}=114.79 \mathrm{~m}^{3} / \mathrm{s}, r=0.86\right.$, $\mathrm{NSE}=0.70$ and $\mathrm{EI}=0.96$; table 5$)$ and groundwater levels within the plain areas of the subcatchment $(\mathrm{RMSE}=0.70-6.5 \mathrm{~m}$; figure 12 ) for independent period.

- A remarkable improvement in prediction of stream flows and groundwater levels has been demonstrated while using distributed Manning's $M$ vis-à-vis corresponding global value of the sub-catchment.

- The water balance of the study region indicated a high value of actual evapotranspiration $(\approx 78 \%)$ during the calibration and validation periods. The percentage error in the water balance of calibrated and validated periods are found to be 1.14 and $1.28 \%$, respectively (table 6 ). The overall simulated water balance component would be very useful for water resources managers in implementation of water conservation measures in the catchment. 
The limitation of foregoing study including future direction for the work as appended below:

- The performance of distributed hydrological model can be improved while giving the gridded rainfall data of the catchment as input to the model instead of using the station based data, as per Thiessen polygon approach, presented in the study.

- The performance of the model can be refined in prediction of groundwater levels of hilly and transitional areas while using Richard's equation instead of 2-layer water balance model for unsaturated porous media.

- The implementation of grid to grid variations in the leaf area index, root depth, soil properties, parameters of aquifers and unsaturated soil may improve the performance of model results.

\section{Acknowledgements}

Authors are thankful to MHRD-NPIU-TEQIP-II for providing the funding through Centre of
Excellence (CoE) Project on 'Water Resources and Flood Management Centre at SVNIT' under which present investigation has been undertaken. Authors are also thankful to India Meteorological Department (IMD), National Remote Sensing Centre (NRSC), Hyderabad, National Bureau of Soil Survey and Land Use Planning (NBSS \& LUP), Nagpur, Central Ground Water Board (CGWB), Nagpur, and Central Water Commission (CWC), Tapi division for providing the data for present study.

\section{Appendix: \\ Statistical performance indices}

The statistical performance indicators enable to evaluate the performance of model from different viewpoints, and would provide a broader appraisal of the developed model. Performance indices (Refsgaard and Knudsen 1996; Lorup et al. 1998; Wang et al. 2012) being used to evaluate the performance of the developed model in present study, are described in table A1.

Table A1. Description of statistical performance indices.

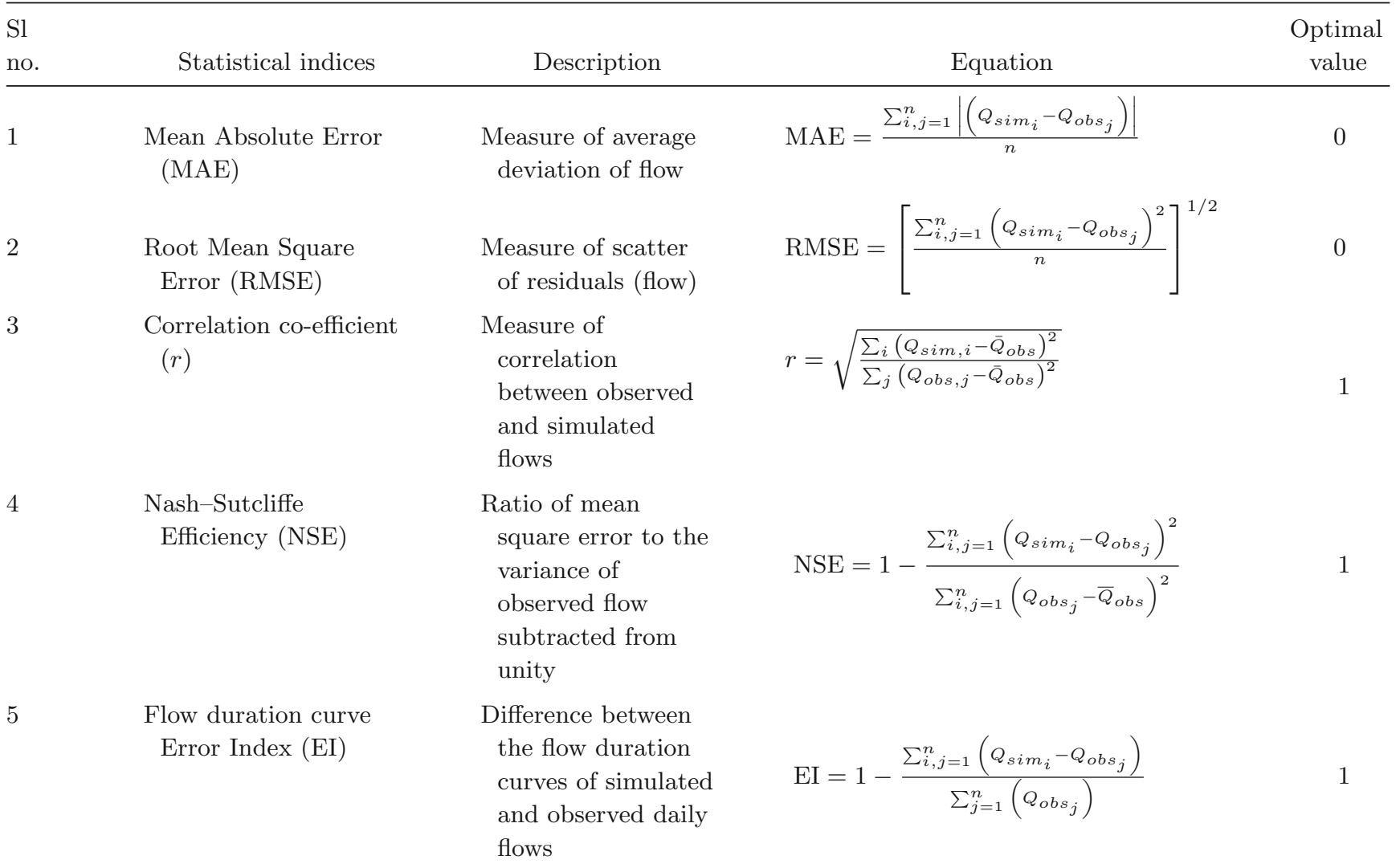

Note: Here, $Q_{s i m, i}$ and $Q_{o b s, j}$ respectively represent observed and simulated values of $j^{\text {th }}$ observation; $n=$ number of observed data points; and $\bar{Q}_{o b s}$ represent mean of observed runoff. 


\section{References}

Allen R G, Pereira L S, Raes D and Smith M 1998 Crop evapotranspiration: Guidelines for computing crop water requirements; FAO Irrigation and Drainage Paper 56, Rome, Italy.

CGWB 2013 Amravati, Akola and Buldana districts profiles, Central Ground Water Board report, New Delhi, India.

Chow V T, Maidment D R and Mays L W 1988 Applied Hydrology; Mcgraw Hill, New York.

Chu M L, Knouft J H, Ghulam A, Guzman J A and Pan Z 2013 Impacts of urbanization on river flow frequency: A controlled experimental modelling-based evaluation approach; J. Hydrol. 495 1-12.

Clausen B and Biggs B J F 2000 Flow variables for ecological studies in temperate streams: Groupings based on covariance; J. Hydrol. 237(3) 184-197.

Dai Z, Li C, Trettin C, Sun G, Amatya D and Li H 2010 Bicriteria evaluation of the MIKE SHE model for a forested watershed on the South Carolina coastal plain; Hydrol. Earth Syst. Sci. 14 1033-1046.

DHI 2017 MIKE SHE User and Reference Manual; Denmark.

El-Nasr A, Arnold J G and Berlamont J 2005 Modelling the hydrology of a catchment using a distributed and a semidistributed model; Hydrol. Pros. 19 573-587.

Engman E T 1986 Roughness coefficients for routing surface runoff; J. Irri. Drain. Engg. 112(1) 39-53.

Foster S B and Allen D M 2015 Groundwater-surface water interactions in a mountain-to-coast watershed: Effects of climate change and human stressors; Adv. Meteorol. $8618051-22$.

GSDA 2004 Dynamic groundwater assessment report (DGAR), Groundwater Survey Development Authority, Maharashtra, India.

Im S, Kim H, Kim C and Jang C 2009 Assessing the impacts of land use changes on watershed hydrology using MIKE SHE; Engg. Geol. 57 231-239.

Jain S K, Agarwal P K and Singh V P 2007 Hydrology and Water Resources of India; Springer Science \& Business Media, India.

Jain P K and Tambe J A 2012 Inland salinity in parts of Purna alluvial basin, Amravati, Akola and Buldhana districts, Maharashtra; Central Ground Water Board report, Nagpur, India.

Kaarlsson I B, Sonnenborg T O, Refsgaard J C, Trolle D, Borgesen C D, Olesen J E, Jeppesen E and Jensen K H 2016 Combined effects of climate models, hydrological model structures and land use scenarios on hydrological impacts of climate change; J. Hydrol. 535 301-317.

Keilholz P, Disse M and Halik U 2015 Effects of land use and climate change on groundwater and ecosystems at the middle reaches of the Tarim river using the MIKE SHE integrated hydrological model; Water 7 3040-3056.

Kothyari U C, Raamsankaran Raaj, Satish Kumar D, Ghosh S K and Mendiratta N 2010 Geospatial based automated watershed modeling in Garhwal Himalaya; J. Hydroinfo. 12(4) 502-520.

Loliyana V D and Patel P L 2015 Lumped conceptual hydrological model for Purna river basin, India; Sadhana 40(8) 2411-2428.
Lorup J K, Christian R J and Mazvimavi D 1998 Assessing the effect of land use change on catchment runoff by combined use of statistical tests and hydrological modeling: Case study from Zimbabwe; J. Hydrol. 205 147-163.

Madsen H 2003 Parameter estimation in distributed hydrological catchment modelling using automatic calibration with multiple objectives; Adv. Water Res. 26 205-216.

Penman H L 1948 Natural evaporation from open water, bare soil, and grass; Proc. Roy. Soc. London 193 120-145.

Qin H, Cao G, Kristensen M, Refsgaard J C, Rasmussen M O, He X, Liu J, Shu Y and Zheng C 2013 Integrated hydrological modeling of the North China plain and implications for sustainable water management; Hydrol. Earth Syst. Sci. 17 3759-3778.

Refsgaard J C 1997 Parameterization, calibration and validation of distributed hydrological model; J. Hydrol. 198 69-97.

Refsgaard J C and Knudsen J 1996 Operational, validation and intercomparison of different types of hydrological models; Water Resour. Res. 32 2189-2202.

Refsgaard J C and Storm B 1995 MIKE SHE; In: Computer Models of Watershed Hydrology (ed.) Singh V P, Water Resources Publications, Highlands Ranch, CO, USA, pp. 809-846.

Rahim B E A, Yusoff I, Jafri A M, Othman Z and Ghani A A 2012 Application of MIKE SHE modelling system to set up a detailed water balance computation; Water Environ. J. 26 490-503.

Sahoo G B, Ray C and De Carlo E H 2006 Calibration and validation of a physically distributed hydrological model, MIKE SHE, to predict streamflow at high frequency in a flashy mountainous Hawaii stream; J. Hydrol. $\mathbf{3 2 7}$ 94-109.

Singh R, Subramanian K and Refsgaard J C 1999 Hydrological modeling of a small watershed using MIKE SHE for irrigation planning; Agr. Water Manag. 41(3) 149-166.

Spinoni J, Vogt J, Naumann G, Carrao H and Barbosa P 2015 Towards identifying areas at climatological risk of desertification using the Köppen-Geiger classification and FAO aridity index; Int. J. Climatol. 35(9) 2210-2222.

Swain J B and Patra K C 2017 Stream flow estimation in ungauged catchments using regional flow duration curve: Comparative study; J. Hydrol. Engg. 22(7), https://doi. org/10.1061/(ASCE)HE.1943-5584.0001509.

Thompson J R, Sorenson H R, Gavin H and Refsgaard A 2004 Application of the coupled MIKE SHE/MIKE 11 modelling system to a lowland wet grassland in southeast England; J. Hydrol. 293(1) 151-179.

UNEP 1992 World Atlas of Desertification; United Nations Environment Programme Edward Arnold, London.

Vázquez R F, Beven K and Feyen J 2009 GLUE based assessment on the overall predictions of a MIKE SHE application; Water Resour. Manag. 23(7) 1325-1349.

Vieux B E 2001 Distributed Hydrologic Modelling Using GIS; Kluwer Academic Publishers, Dordrecht, The Netherlands.

Vo N D and Gourbesville P 2016 Application of deterministic distributed hydrological model for large catchment: A case study at $\mathrm{Vu}$ Gia Thu Bon catchment, Vietnam; J. Hydroinfor. 18(5) 885-904.

Wang S, Zhang Z, Sun G, Strauss P, Guo J, Tang Y and Yao A 2012 Multi-site calibration, validation, and sensitivity 
analysis of the MIKE SHE model for a large watershed in northern China; Hydrol. Earth Syst. Sci. 16 4621-4632.

Wijesekara G N, Farjad B, Gupta A, Qiao Y, Delaney P and Marceau D J 2014 A comprehensive land-use/hydrological modeling system for scenario simulations in the Elbow river watershed, Alberta, Canada; Environ. Manag. 53 $357-381$.

Corresponding editor: Subimal GHosh
Yan J and Smith K R 1994 Simulations of integrated surface water and ground water systems - model formulation; J. Am. Water Resour. Assoc. 30(5) 879-890.

Zhang Z, Wang S, Sun Ge, McNulty S G, Zhang H, Li J, Zhang M, Klaghofer E and Strauss P 2008 Evaluation of the MIKE SHE model for application in the loess plateau, China; J. Am. Water Resour. Assoc. 44(5) 1108-1119. 